In cooperation with the Orange County Commissioner's Court

\title{
Ground-Water Data in Orange County and Adjacent Counties, Texas, 1985-90
}

Open-File Report 99-603

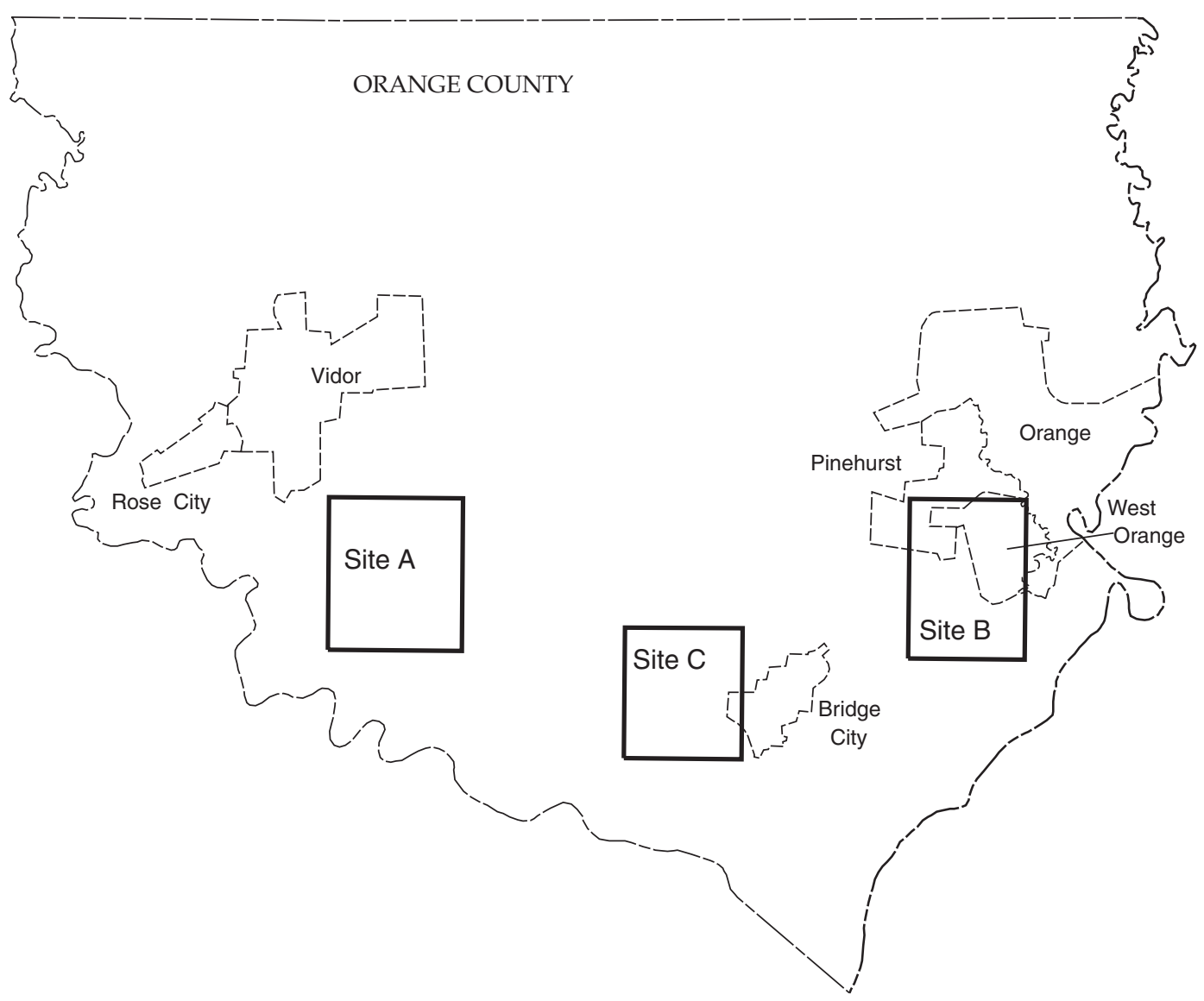

U.S. Department of the Interior

U.S. Geological Survey 
U.S. Department of the Interior

U.S. Geological Survey

\section{Ground-Water Data in Orange County and Adjacent Counties, Texas, $1985-90$}

By Mark C. Kasmarek

U.S. GEOLOGICAL SURVEY

Open-File Report 99-603

In cooperation with the Orange County Commissioner's Court

Austin, Texas

1999 


\section{U.S. DEPARTMENT OF THE INTERIOR}

Bruce Babbitt, Secretary

\section{U.S. GEOLOGICAL SURVEY}

Charles G. Groat, Director

Any use of trade, product, or firm names is for descriptive purposes only and does not imply endorsement by the U.S. Government.

For additional information write to

\section{District Chief}

U.S. Geological Survey

8027 Exchange Dr.

Austin, TX 78754-4733

E-mail: dc_tx@usgs.gov

Copies of this report can be purchased from

U.S. Geological Survey

Branch of Information Services

Box 25286

Denver, CO 80225-0286

E-mail: infoservices@usgs.gov 


\section{CONTENTS}

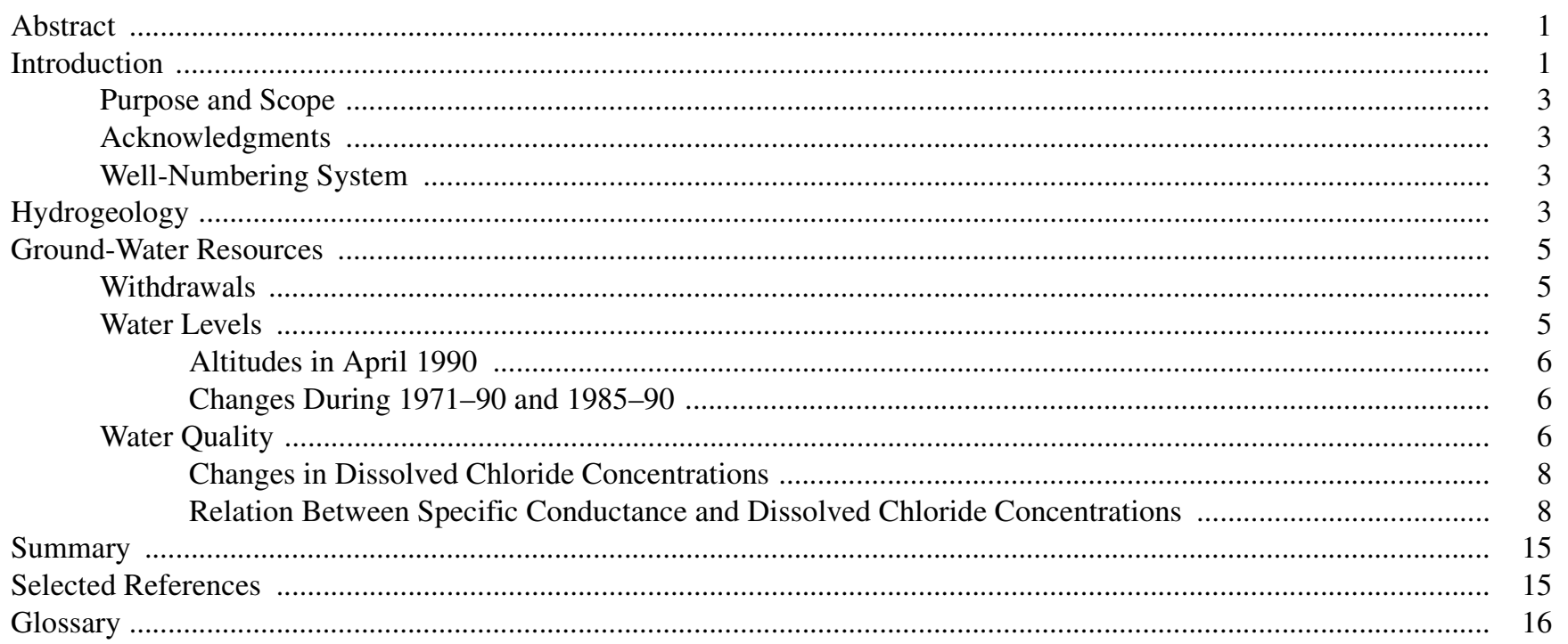

\section{PLATES}

Plates are in pocket

1-5. Maps showing:

1. Locations of selected wells in Orange County and adjacent counties, Texas

2. Approximate water-level altitudes in wells screened in the lower unit of the Chicot aquifer in Orange County and adjacent counties, Texas, 1990

3. Approximate water-level changes in wells screened in the lower unit of the Chicot aquifer in Orange County and adjacent counties, Texas, 1971-90

4. Approximate water-level changes in wells screened in the lower unit of the Chicot aquifer in Orange County and adjacent counties, Texas, 1985-90

5. Distribution of dissolved chloride concentrations in water from wells screened in the lower unit of the Chicot aquifer in Orange County, Texas, November-December 1989

\section{FIGURES}

1-2. Maps showing:

1. Location of study area

2. Approximate altitude of the base of the Chicot aquifer in Orange County, Texas

3. Hydrographs showing changes in water levels in wells screened in the lower unit of the Chicot aquifer in Orange County, Texas

4. Conceptual profiles showing (a) relation between freshwater and saline water before pumping begins and (b) development of a saline-water cone during pumping

5-6. Maps showing dissolved chloride concentrations in water from selected wells screened in the lower unit of the Chicot aquifer at:

5. Site A in southwestern Orange County, Texas, November 1985

6. Site B in southeastern Orange County, Texas, (a) November 1985, (b) October-November 1986, and (c) October 1988

7. Graph showing relation between specific conductance and dissolved chloride concentrations in water from wells screened in the lower unit of the Chicot aquifer, Orange County, Texas, 1985-89 


\section{TABLES}

1. Hydrogeologic correlations for Orange County and adjacent counties, Texas

2. Average daily rates of ground-water withdrawals for municipal and industrial use from the lower unit of the Chicot aquifer in Orange County, Texas, 1980-89, in million gallons per day

3. Average daily rates of ground-water withdrawals from the lower unit of the Chicot aquifer at major industrial sites in Orange County, Texas, 1980-89, in million gallons per day

4. Average daily rates of surface water supplied for municipal and industrial use in Orange County,

Texas, 1980-89, in million gallons per day

5. Average daily rates of ground-water withdrawals from the Evangeline aquifer and lower unit of the Chicot aquifer for public supply in eastern Jefferson, eastern Hardin, and southern Jasper Counties, Texas, 1985-89, in million gallons per day

6. Water levels in observation wells in Orange County and adjacent counties, Texas, 1985-90

7. Records of selected wells in Orange County, Texas, 1985-90

8. Chemical analyses of water from selected wells in Orange County, Texas, 1985-90 28

\section{VERTICAL DATUM AND ABBREVIATIONS}

Sea level: In this report "sea level" refers to the National Geodetic Vertical Datum of 1929 (NGVD of 1929)—a geodetic datum derived from a general adjustment of the first-order level nets of both the United States and Canada, formerly called Sea Level Datum of 1929.

\section{Abbreviations:}

${ }^{\circ} \mathrm{C}$, degree Celsius

$\mathrm{ft}$, foot

in., inch

$\mathrm{mg} / \mathrm{L}$, milligram per liter

mi, mile

$\mathrm{Mgal} / \mathrm{d}$, million gallons per day

$\mu \mathrm{S} / \mathrm{cm}$, microsiemens per centimeter at 25 degrees Celsius 


\title{
Ground-Water Data in Orange County and Adjacent Counties, Texas, 1985-90
}

\author{
By Mark C. Kasmarek
}

\section{Abstract}

The lower unit of the Chicot aquifer is a major source of freshwater for Orange County, Texas. In 1989, the average rate of ground-water withdrawal from the lower unit of the Chicot aquifer in Orange County for municipal and industrial use was 13.8 million gallons per day, a substantial decrease from the historical high of 23.1 million gallons per day in 1972. The average withdrawal for industrial use decreased substantially from 14.4 million gallons per day during 1963-84 to 6.9 million gallons per day during 1985-89. The average withdrawal for municipal use during 1985-89 was 6.8 million gallons per day, similar to the average withdrawal of 5.8 million gallons per day during 1963-84.

Water levels in wells in most of the study area rose during 1985-90. The largest rise in water levels was more than 10 feet in parts of Orange and Pinehurst, north of site B (one of three areas of ground-water withdrawal for industrial use), while the largest decline in water levels was a localized decline of more than 60 feet at site $C$ in southcentral Orange County (also an area of withdrawal for industrial use).

Chemical analyses of ground-water samples from the lower Chicot aquifer during 1985-90 indicate that the aquifer contained mostly freshwater (dissolved solids concentrations less than 1,000 milligrams per liter). Dissolved chloride concentrations remained relatively constant in most wells during 1985-90 but could vary greatly between wells within short distances. Saline-water encroachment continued to occur during 1985-89 but at a slower rate than in the 1970s and early 1980s. On the basis of chemical data collected during 1985-89, a relation was determined between specific conductance and dissolved chloride concentration that can be used to estimate dissolved chloride by multiplying the specific conductance by different factors for low or high conductances.

\section{INTRODUCTION}

A continuing program to study the ground-water resources in Orange County and adjacent counties in Texas was begun in March 1967 by the U.S. Geological Survey in cooperation with the Texas Water Development Board and the Sabine River Authority. Since 1979, this program has been conducted in cooperation with the Orange County Commissioner's Court. Orange County is the principal part of the study area (fig. 1) where data were collected pertinent to the ground-water resources. Ancillary data were collected in adjacent Hardin, Jasper, Jefferson, and Newton Counties.

The ground-water program, which consists of monitoring and appraising withdrawals of ground water, water levels, and water quality, was initiated to document water-level changes and saline-water encroachment. The overall objectives of the program are to provide the following:

1. An inventory of all new large-capacity wells and the compilation of drillers logs.

2. The establishment and maintenance of a network of observation wells for monitoring changes in water levels and water quality, especially dissolved chloride concentrations.

3. An annual inventory of withdrawal for municipal supply and industrial use.

4. The correlation of current data with previously collected data. 


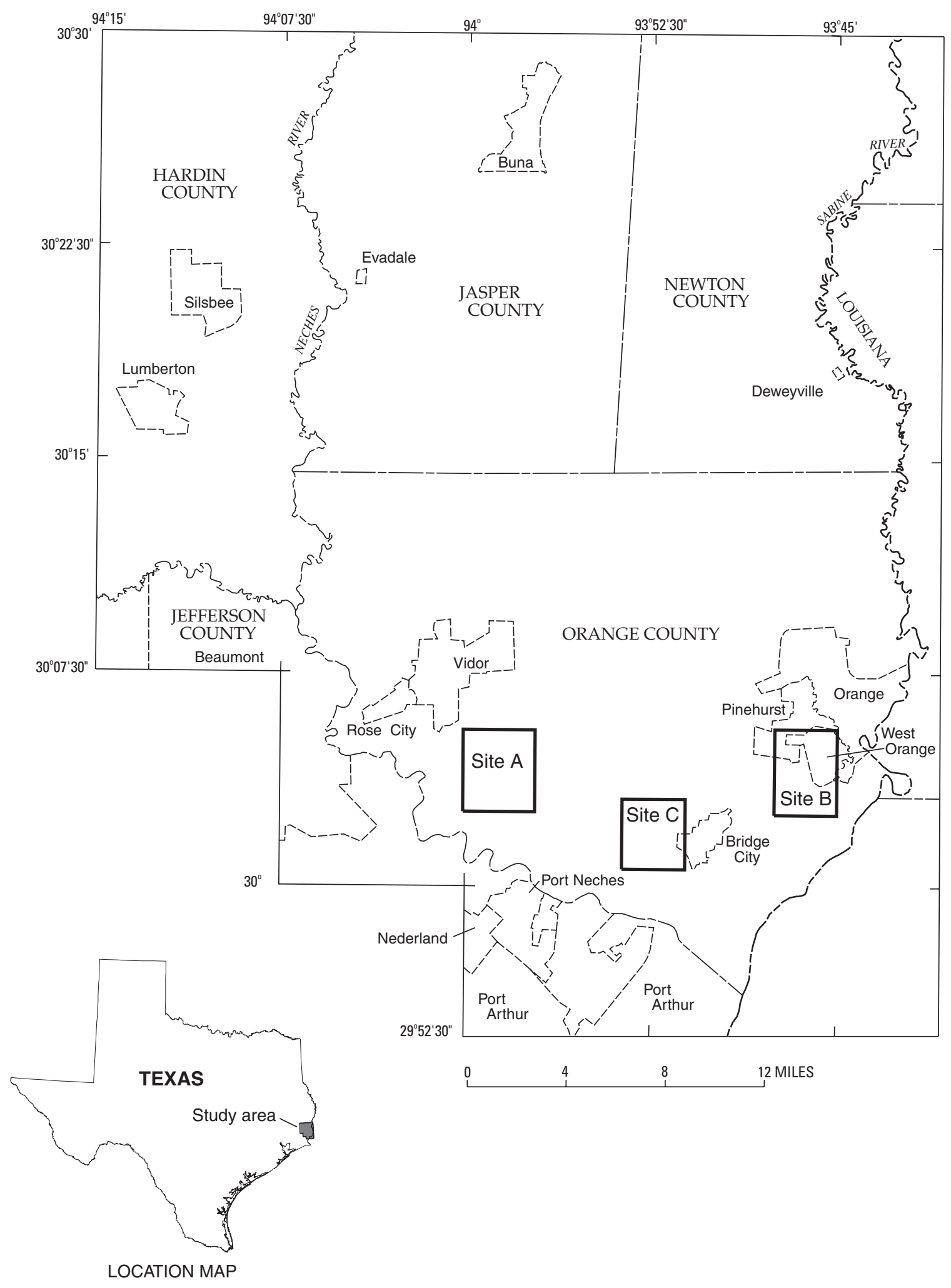

Figure 1. Location of study area. 


\section{Purpose and Scope}

This report presents a brief discussion on the hydrogeology of the area and an evaluation of the ground-water data collected during April 1985-April 1990. The data include ground-water withdrawals from the Chicot and Evangeline aquifers, water-level altitudes and changes in wells in the Chicot aquifer, and water quality in wells in the Chicot aquifer.

\section{Acknowledgments}

Special thanks are extended to the many land owners and industry and city officials who provided data and granted access to water-well sites. Mr. Bill Moltz, Texas Water Development Board, Austin, Texas, tabulated the ground-water withdrawal and surfacewater pumpage data used in this report.

\section{Well-Numbering System}

The well-numbering system in Texas was developed by the Texas Water Development Board for use throughout the State. Under this system, each 1-degree quadrangle is given a number consisting of two digits. These are the first two digits in the well number. Each 1-degree quadrangle is divided into 7-1/2-minute quadrangles that are given a two-digit number from 01 to 64 . These are the third and fourth digits of the well number. Each 7-1/2-minute quadrangle is divided into 2-1/2-minute quadrangles that are given a single-digit number from 1 to 9 . This is the fifth digit of the well number. Finally, each well within a 2-1/2-minute quadrangle is given a 2-digit number in the order in which it was inventoried, starting with 01. These are the last two digits of the well number.

In addition to the seven-digit well number, a twoletter prefix is used to identify the county where the well is located. The prefixes for the counties in the study are: Orange, UJ; Hardin, LH; Jasper, PR; Jefferson, PT; and Newton, TZ.

On plate 1, only the last three digits of the well number are shown at each well location where data were collected; the second two digits are shown in the corner of each 7-1/2-minute quadrangle; and the first two digits are shown by the large block numerals adjacent to each 1-degree quadrangle. Plate 1 shows the locations of wells that were inventoried during 1985-90 plus locations of a representative number of wells inventoried during preceding periods.

\section{HYDROGEOLOGY}

The hydrologic and geologic units in Orange County have been described by Wesselman (1965), Gabrysch and McAdoo (1972), and Nyman (1984). Harder (1960) and Harder and others (1967) defined the hydrologic units in southwestern Louisiana. This report uses the classification of Nyman (1984) with slight modification. Hydrogeologic correlations for Orange County and adjacent counties are summarized in table 1 (at end of report).

The Chicot aquifer, underlying all of the study area at various depths, stratigraphically is the shallowest principal aquifer in the study area and is of Pleistocene age. The Chicot aquifer is divided into two sand units by clay beds that, although not areally continuous, do separate an upper sand unit from a lower sand unit stratigraphically (table 1). The altitude of the base of the Chicot aquifer ranges from less than $400 \mathrm{ft}$ below sea level in northwestern Orange County to about 1,000 ft below sea level in southeastern Orange County (fig. 2). Electric logs of some wells show a thick high-resistivity sand at the base of the Chicot aquifer, and this sand acts as a well-defined markerbed (Turcan and others, 1966). The lower unit of the Chicot aquifer is a major source of freshwater for Orange County.

The Evangeline aquifer underlies the Chicot aquifer and consists of sediments of Pliocene and Miocene age. The differentiation of the Evangeline aquifer from the Chicot aquifer is made on the basis of grain size. The Evangeline aquifer consists of finer grained sediments than the Chicot aquifer, which consists chiefly of coarse sand and gravel and has a greater sand-to-clay ratio. The sediments of the Evangeline aquifer are less permeable and have lower rates of transmissivity than the Chicot aquifer. Laterally continuous clay beds are not present to separate the two aquifers; this lack of clay beds allows the waters of the aquifers to intermix. The amount of intermixing is dependent on the fluctuating 


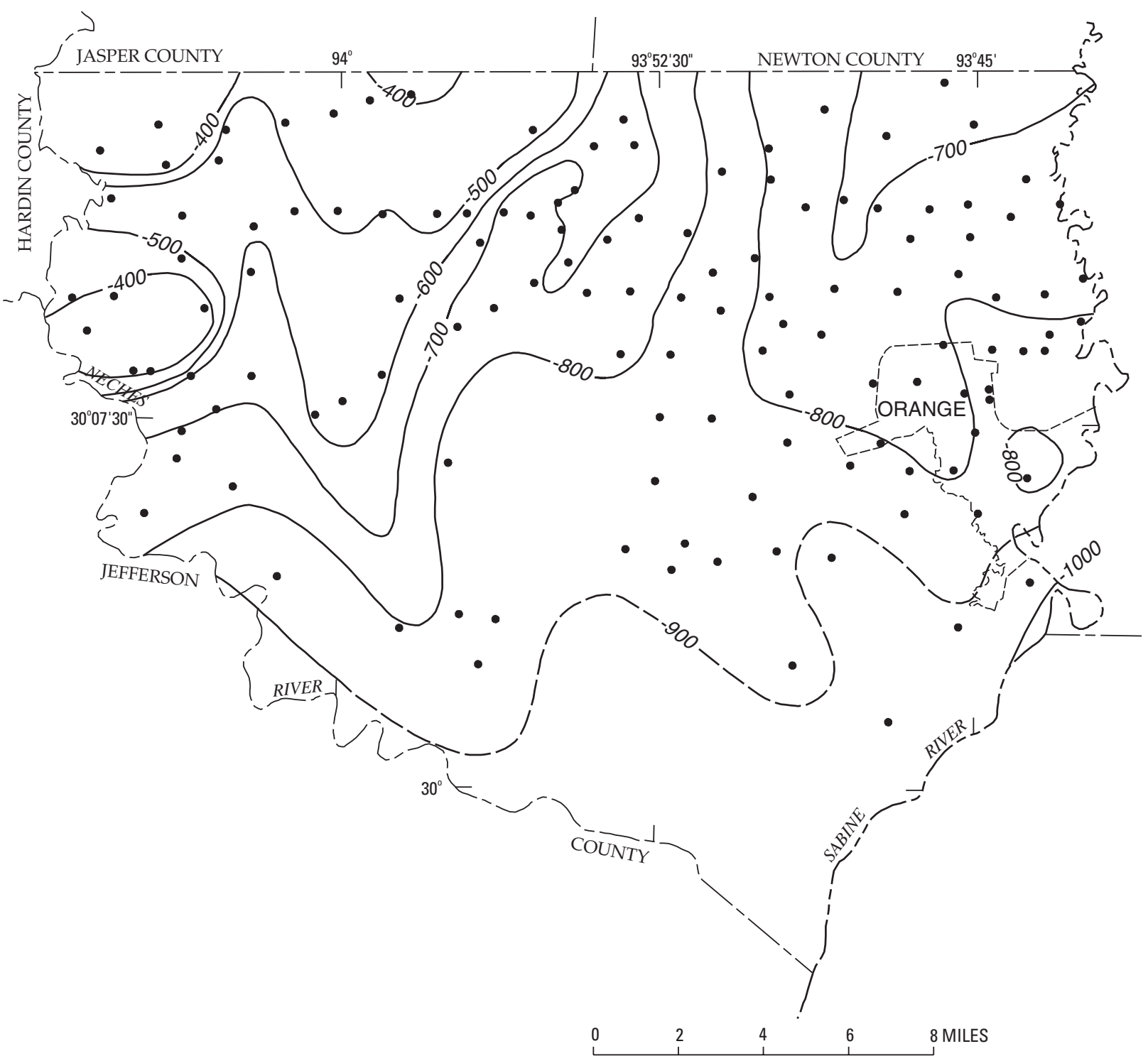

EXPLANATION

-800 - - Structure contour-Shows altitude of base of Chicot aquifer. Dashed where approximately located. Contour interval 100 feet. Datum is sea level

- Well used for control

Figure 2. Approximate altitude of the base of the Chicot aquifer in Orange County, Texas (modified from Gabrysch and McAdoo, 1972). 
hydraulic gradient caused by withdrawal at concentrated pumping centers like those at sites A, B, and C (fig. 1). The Evangeline aquifer contains freshwater only in the extreme northwestern part of Orange County.

\section{GROUND-WATER RESOURCES}

\section{Withdrawals}

Ground-water withdrawals from the lower unit of the Chicot aquifer during 1985-89 were reported by major water users to the Texas Water Development Board. Information on ground-water withdrawals during 1963-84 were published in a previous report (Bonnet and Williams, 1987, p. 13). Average daily rates of ground-water withdrawals from the lower unit of the Chicot aquifer in Orange County during 1980-89 are listed in table 2 (at end of report). The data for 1980-84 are included to indicate historical trends.

The major water users in Orange County did not report any ground-water withdrawals from the upper unit of the Chicot aquifer during 1980-89. Consequently, the withdrawals from this unit are unknown but are believed to be isolated and few.

Average daily rates of ground-water withdrawals for combined municipal and industrial use in Orange County ranged from 13.1 to $20.1 \mathrm{Mgal} / \mathrm{d}$ during 1980-89 and ranged from 13.1 to $14.6 \mathrm{Mgal} / \mathrm{d}$ during 1985-89. Because of declining economic conditions and recycling of some of the water used for industrial purposes, the average withdrawal of $6.9 \mathrm{Mgal} / \mathrm{d}$ during 1985-89 for industrial use was a substantial decrease from the average of $14.4 \mathrm{Mgal} / \mathrm{d}$ during 1963-84 (Bonnet and Williams, 1987, table 2). This is in contrast to the average withdrawal of about $6.8 \mathrm{Mgal} / \mathrm{d}$ during 1985-89 for municipal use, which was a $1.0 \mathrm{Mgal} / \mathrm{d}$ increase over the average of $5.8 \mathrm{Mgal} / \mathrm{d}$ during 1963-84 (Bonnet and Williams, 1987, table 2). During 1985-89, withdrawals for municipal use ranged from 6.4 to 7.1 $\mathrm{Mgal} / \mathrm{d}$, similar to withdrawals for industrial use, which ranged from 6.4 to $7.5 \mathrm{Mgal} / \mathrm{d}$. The combined municipal and industrial average ground-water withdrawal in 1989 was $13.8 \mathrm{Mgal} / \mathrm{d}$, a substantial decrease from the historical high of $23.1 \mathrm{Mgal} / \mathrm{d}$ in 1972 (Bonnet and Williams, 1987, table 2). Most ground water used for industrial purposes was withdrawn at three locations: southeast of the city of Vidor (site A); southwest of the city of Orange, which includes the petrochemical industrial area (site B); and south-central Orange County (site C) (fig. 1). Average daily rates of ground-water withdrawals at these sites during 1980-89 are listed in table 3 (at end of report). The average daily rates of ground-water withdrawals show little year-toyear variability at each location during 1985-89 and were less than the rates during 1980-84.

Surface-water use in Orange County during 1980-89 (table 4 at end of report) was considerably more than ground-water use. Surface water supplied for municipal and industrial use was about 2.5 times the ground-water withdrawals for municipal and industrial use in 1980 and more than 3 times the withdrawals in 1989.

Water for the cities of Beaumont in Jefferson County, Silsbee and Lumberton in Hardin County, and Buna and Evadale in Jasper County is pumped from wells with screened intervals in the Chicot and Evangeline aquifers; therefore, the withdrawal from each individual aquifer is unknown. The estimated ground-water withdrawals during 1985-89 from the Evangeline aquifer and lower unit of the Chicot aquifer for these municipalities are listed in table 5 (at end of report).

\section{Water Levels}

Static water-level measurements, used to prepare regional water-level altitude maps, are made in the spring of each year when ground-water withdrawals are minimal (principally as a result of decreased agricultural withdrawals) and when ground-water levels usually are at their highest altitude. Measurements made during 1985-90 are listed in table 6 (at end of report).

Water-level measurements made before 1985 in wells located in the western part of Louisiana adjacent to the Sabine River were used to prepare water-level maps for previous reports (Gabrysch and McAdoo, 1972; Bonnet, 1975; Bonnet and Gabrysch, 1983; and Bonnet and Williams, 1987). Measurements were not made in those wells during 1985-89 because the program that covered this geographic area in Louisiana was discontinued. 


\section{Altitudes in April 1990}

The approximate altitudes of water levels measured in wells screened in the lower unit of the Chicot aquifer during April 1990 are shown in plate 2. Water levels in wells in Orange County were about 20 to $30 \mathrm{ft}$ below sea level in the central and west-central parts; about 10 to $20 \mathrm{ft}$ below sea level in the northern part; about 30 to more than $40 \mathrm{ft}$ below sea level in the eastern part near the city of Orange; and about 20 to more than $90 \mathrm{ft}$ below sea level in south-central Orange County at site $\mathrm{C}$.

\section{Changes During 1971-90 and 1985-90}

Water-level changes during 1971-90 (pl. 3) generally ranged from a decline of more than $20 \mathrm{ft}$ to a rise of more than $10 \mathrm{ft}$. However, in south-central Orange County, concentrated pumping at site $\mathrm{C}$ resulted in estimated declines of more than $10 \mathrm{ft}$. Water levels in wells rose more than $10 \mathrm{ft}$ south of the city of Orange near the petrochemical industrial area in and near site B. Water levels in wells in Vidor declined as much as $5 \mathrm{ft}$ in the northwestern part of the city, and rose less than $5 \mathrm{ft}$ in the eastern part.

Water-level changes during 1985-90 (pl. 4) ranged from a localized decline of more than $60 \mathrm{ft}$ at site $\mathrm{C}$ in south-central Orange County, to a local rise of more than $10 \mathrm{ft}$ in parts of Orange and Pinehurst, north of site B. Water levels generally remained about constant in West Orange and at site B in the petrochemical industrial area. Near Vidor and at site A, water levels in wells rose less than $10 \mathrm{ft}$. The general rise in water levels during 1985-90 throughout most of Orange County is related to the decrease in withdrawal rates (tables 2 and 3 ) resulting from the decline in economic conditions and the reuse of some of the ground water pumped for industrial purposes during that period.

Long-term hydrographs of four wells in the study area are shown in figure 3. Well UJ-62-51-103 is located in the northeast corner of Orange County; well UJ-62-57-401 is located in southwestern Orange County; and wells UJ-62-59-105 and UJ-62-59-123 are located in the city of Orange (pl. 1). The hydrographs in figure 3 show declining water levels into the early to mid-1970s, at which time water levels stabilized. In the early 1980s, water levels slowly began to rise. Hydrographs of wells UJ-62-51-103 and UJ-62-57-401 show net water-level rises of about
1.7 and $8 \mathrm{ft}$, respectively, from 1985 to 1990 . The hydrograph of water levels in well UJ-62-59-123 shows a net water-level rise of about $2.4 \mathrm{ft}$ from 1966 to 1990 , and the hydrograph of water levels in well UJ-62-59-105, which was discontinued in August 1987, shows a net water-level decline of about $22 \mathrm{ft}$ from 1952 to 1987 . The records of selected wells for newly inventoried sites during 1985-90 are presented in table 7 (at end of report). Records of older wells in Orange County and vicinity are given in various previous reports such as Bonnet (1975), Bonnet and Gabrysch (1983), Bonnet and Williams (1987), Gabrysch and McAdoo (1972), McAdoo (1968-70), and Wesselman (1965).

\section{Water Quality}

The chemical analyses of water samples collected from selected wells during 1985-90 are listed in table 8 (at end of report). The analyses consisted of specific conductance, $\mathrm{pH}$, temperature (all determined in the field), and dissolved chloride concentration (determined in the laboratory). In 1985 the specific conductance ranged from 180 to $4,140 \mu \mathrm{S} / \mathrm{cm}$ in water from wells UJ-62-49-302 and UJ-62-58-605, respectively. The $\mathrm{pH}$ ranged from 6.6 standard units in water from wells UJ-62-50-106 (November 29, 1989) and UJ-62-58-305 (October 27, 1987) to 8.4 standard units in water from well UJ-62-57-401 (December 6, 1989). Water temperature ranged from $18.0^{\circ} \mathrm{C}$ in well UJ-62-50-807 on November 29,1989 , to $26.0^{\circ} \mathrm{C}$ in well UJ-62-58-608 on October 18, 1988. The dissolved chloride concentrations ranged from $14 \mathrm{mg} / \mathrm{L}$ in water collected from well UJ-62-49-905 (November $12,1985)$ to $1,200 \mathrm{mg} / \mathrm{L}$ in well UJ-62-58-605 (November 14, 1985; November 6, 1986; October 26, 1988). Most of the wells sampled in the lower Chicot aquifer during 1985-89 contained freshwater (dissolved solids concentrations less than $1,000 \mathrm{mg} / \mathrm{L}$ (Winslow and Kister, 1956)). Furthermore, dissolved chloride concentrations in water from most wells in the lower Chicot aquifer within the study area showed little variation during 1985-90.

Secondary maximum contaminant levels (SMCL), nonenforceable guidelines based on taste, odor, and color, were established by the U.S. Environmental Protection Agency (1996) for selected properties and constituents in drinking water. $\mathrm{pH}$ in samples 

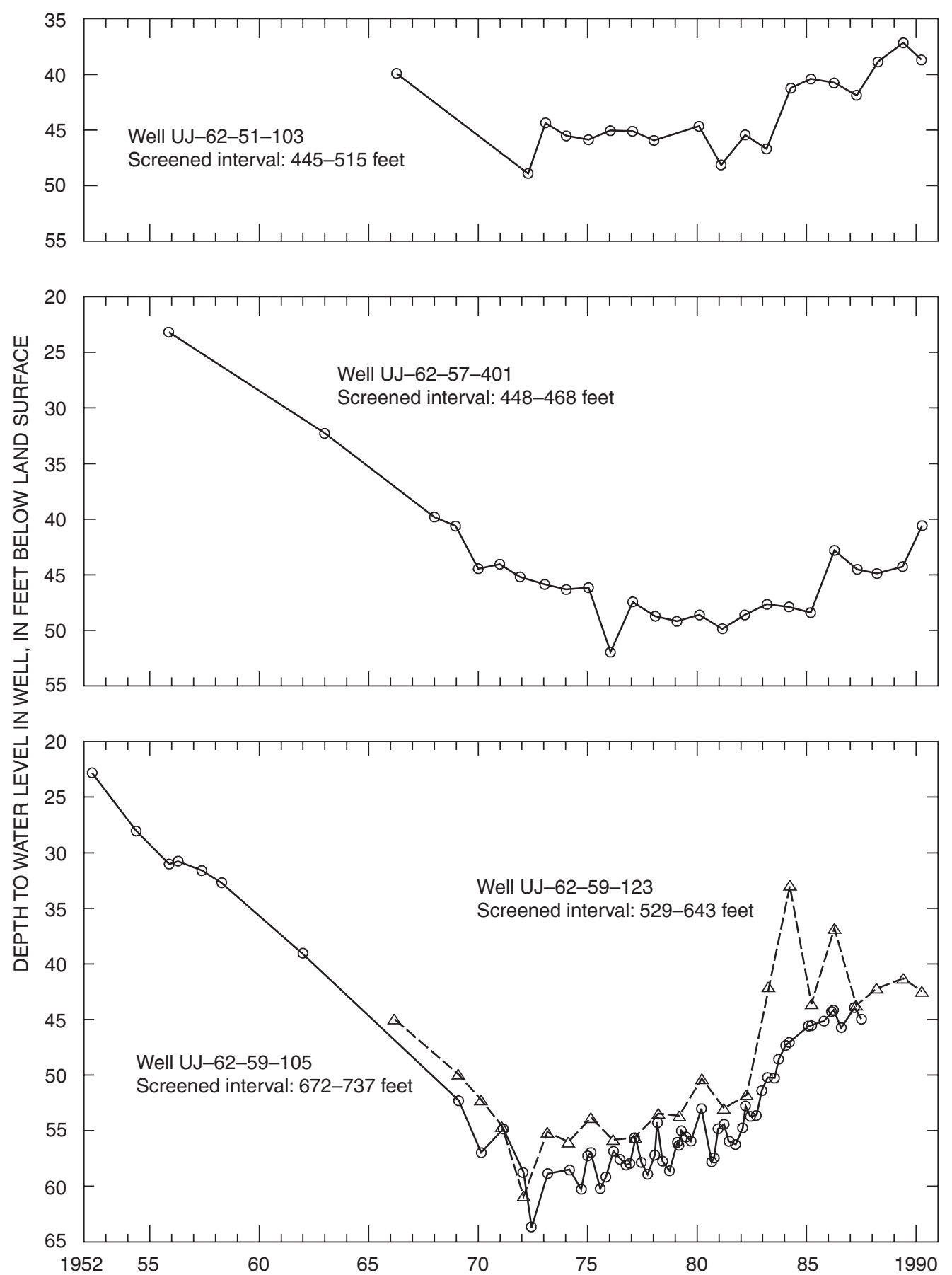

NOTE: Points show water levels at time of

measurements. Lines between points

indicate trend, but actual water levels

may have diverged from indicated trends.

Figure 3. Hydrographs showing changes in water levels in wells screened in the lower unit of the Chicot aquifer in Orange County, Texas. 
collected during 1985-90 (table 8) from public-supply, livestock, and domestic wells was within the SMCL range of 6.5 to 8.5 standard units. During 1985-90, dissolved chloride concentrations (table 8) in many wells at sites A and B (where the majority of industrial wells are located) were greater than the SMCL of $250 \mathrm{mg} / \mathrm{L}$. However, most of the wells in the northern two-thirds of the county (where the majority of publicsupply, livestock, and domestic wells are located) had dissolved chloride concentrations less than $250 \mathrm{mg} / \mathrm{L}$; many of these wells had concentrations less than $100 \mathrm{mg} / \mathrm{L}$.

The geographic distribution of dissolved chloride concentrations in water from wells screened in the lower unit of the Chicot aquifer in Orange County during November-December 1989 is shown in plate 5 . Sites A and B, areas with large rates of ground-water withdrawal in Orange County, had the largest dissolved chloride concentrations, ranging from 290 to $740 \mathrm{mg} / \mathrm{L}$, and some of the smallest dissolved chloride concentrations, $20 \mathrm{mg} / \mathrm{L}$ at site $\mathrm{B}$ and $28 \mathrm{mg} / \mathrm{L}$ at site $\mathrm{A}$.

\section{Changes in Dissolved Chloride Concentrations}

In coastal areas, many aquifers historically (before development) have contained freshwater and saline water, with the less dense freshwater above the more dense saline water. Ground-water withdrawal can cause mixing of freshwater and saline water within the aquifer depending on numerous factors, the most important being hydrogeologic properties of the aquifer; altitude of the freshwater/saline-water interface; depth of screened intervals in wells; and rate of groundwater withdrawal from wells. A well, or more commonly a site with numerous wells, with a large rate of ground-water withdrawal can cause the saline water to be drawn upward towards the land surface and into the screened interval. This saline-water encroachment causes an increase in the dissolved chloride concentration of the water and can result in saline-water "upconing." Conceptualized profiles of this process are shown in figure 4 . This process is indicated when a well (or group of wells) with water having a large dissolved chloride concentration is surrounded by wells (screened at essentially the same interval) with water having smaller dissolved chloride concentrations. The dissolved chloride concentrations in water from several wells at site A were measured in November 1985 (fig. 5). The dissolved chloride concentration in water from well UJ-62-57-404 was substantially greater than concentrations from five of the wells surrounding it, indicating upconing at this site.

Saline-water encroachment is shown by data at site B near the city of Orange (fig. 6). The dissolved chloride concentrations in water from wells located at site B ranged from $14 \mathrm{mg} / \mathrm{L}$ in the central part of the site in 1972 to $1,500 \mathrm{mg} / \mathrm{L}$ in the southwestern part in 1974 (Bonnet, 1975, table 3). During 1985-89, dissolved chloride concentrations ranged from $21 \mathrm{mg} / \mathrm{L}$ in water from well UJ-62-58-642 in the central part of site B to 1,200 mg/L in water from well UJ-62-58-605 in the southwestern part of site B (table 8).

The steepness of the slope of the freshwater/ saline-water interface is shown by dissolved chloride concentrations in water from two wells, UJ-62-58-605 and UJ-62-58-635, located within 0.2 mi of each other (fig. 6). The wells are screened at comparable depths and yielded water in November 1985 with dissolved chloride concentrations of 1,200 and $34 \mathrm{mg} / \mathrm{L}$, respectively (fig. 6a). The concentrations of dissolved chloride in water from these two wells were 1,200 and $34 \mathrm{mg} / \mathrm{L}$, respectively, in November 1986 (fig. 6b) and 1,100 and $31 \mathrm{mg} / \mathrm{L}$, respectively, in November 1987 (table 8). Samples for chemical analyses were not collected from well UJ-62-58-635 in 1988 or 1989.

To mitigate the effects of saline-water encroachment, ground-water users in areas of Orange County with large rates of ground-water withdrawal and subsequent elevated dissolved chloride concentrations used the following techniques: alternating pumping between available wells; carefully monitoring withdrawal rates, specific conductivities, and dissolved chloride concentrations; supplementing ground-water withdrawals with surface-water pumpage; and recycling the water used for industrial purposes.

\section{Relation Between Specific Conductance and Dissolved Chloride Concentrations}

A generalized relation between specific conductance and dissolved chloride concentration in water from wells screened in the lower unit of the Chicot aquifer in Orange County and sampled during 1985-89 is 

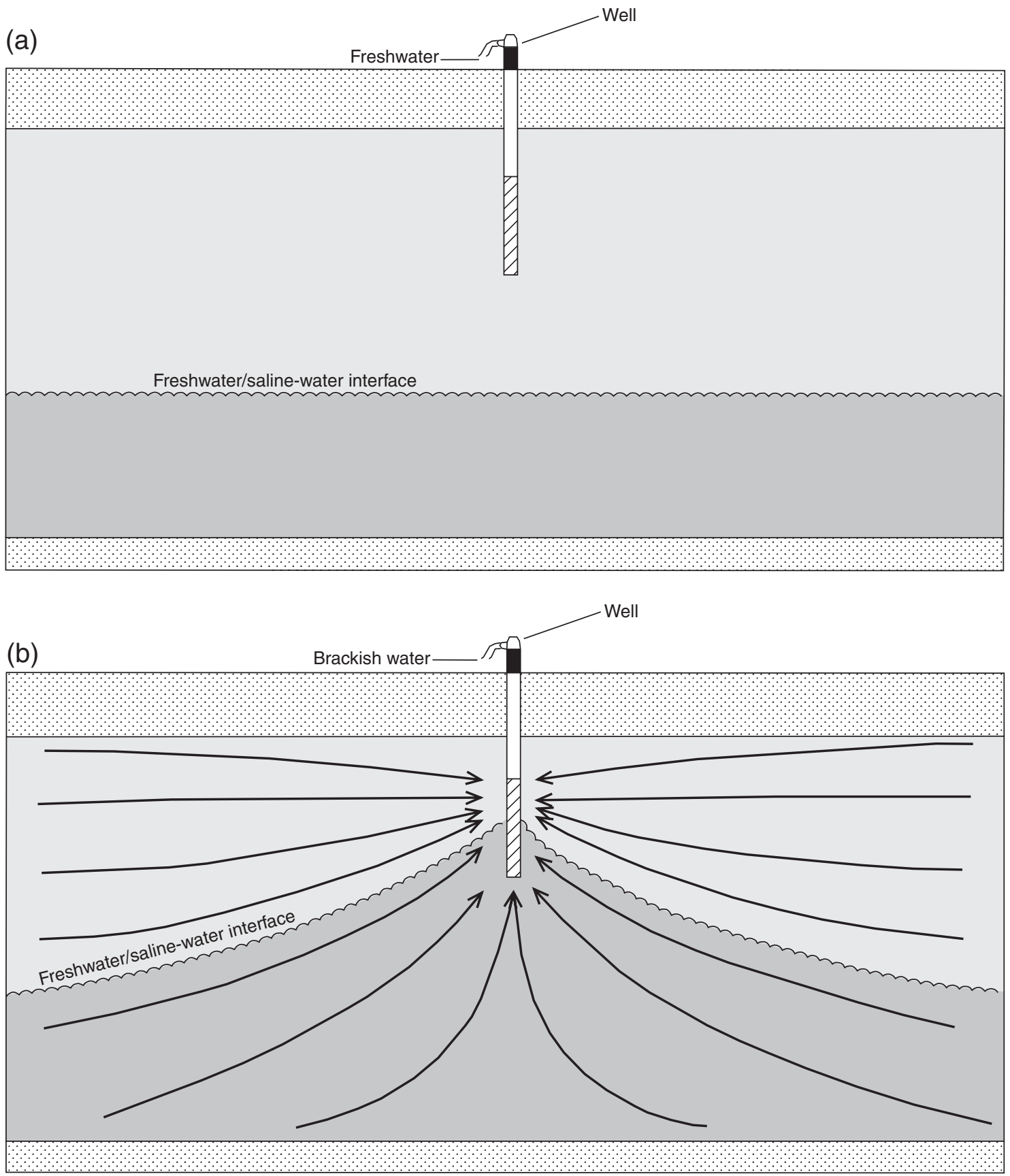

\section{EXPLANATION}

Sand containing freshwater

Sand containing saline water

Mostly clay

$\triangle$ Screen in well

Figure 4. Conceptual profiles showing (a) relation between freshwater and saline water before pumping begins and (b) development of a saline-water cone during pumping (modified from Nyman, 1984). 


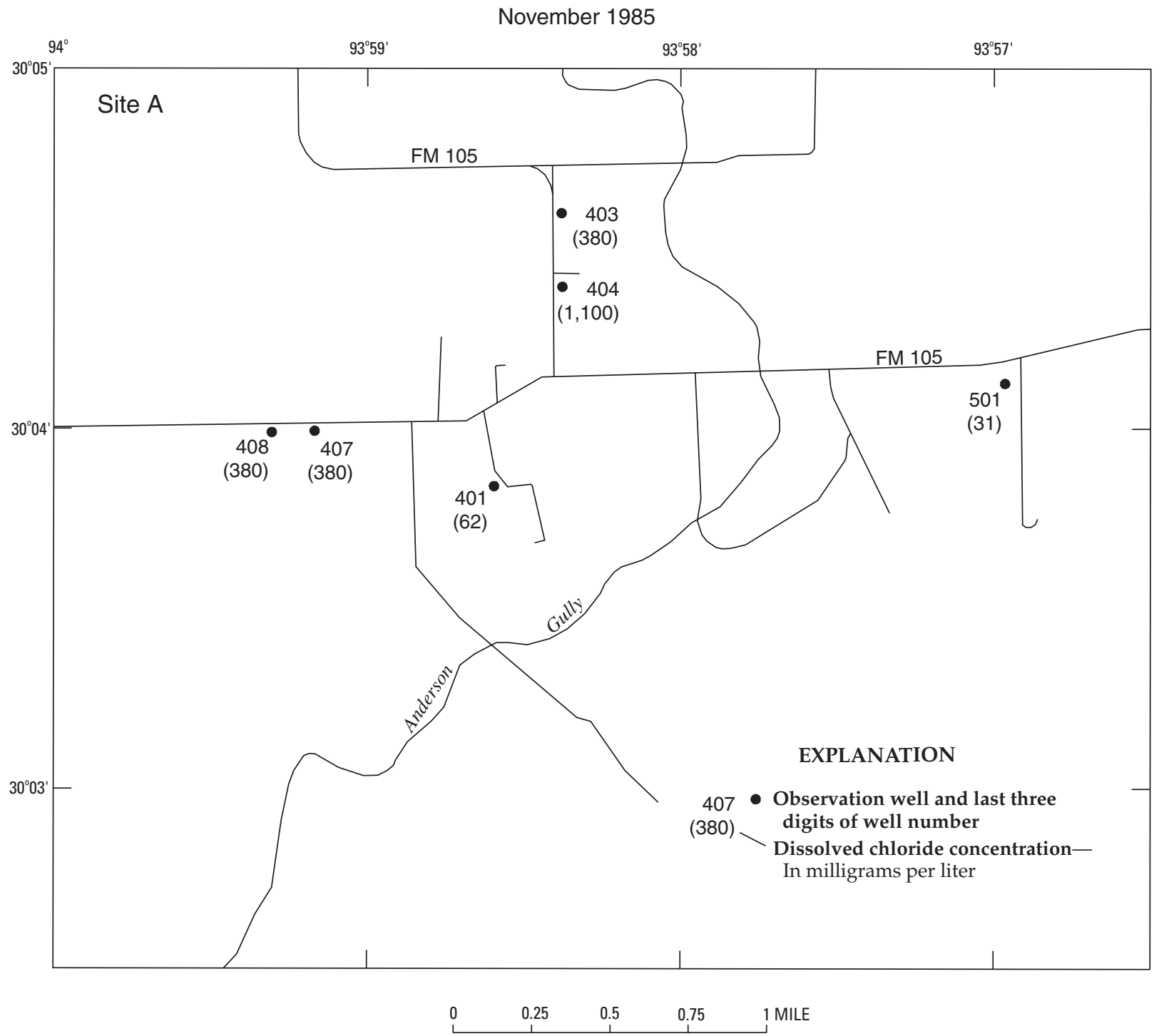

Figure 5. Dissolved chloride concentrations in water from selected wells screened in the lower unit of the Chicot aquifer at site A in southwestern Orange County, Texas, November 1985.

shown in figure 7. A statistical linear regression was used to determine a line that best fit all data using the equation:

Dissolved chloride

$$
\text { concentration }=(3.1759) \text { specific conductance }
$$$$
+325.2591 \text {. }
$$

As shown by figure 7, the relation between these two constituents is approximately linear when specific conductances range between 800 and 2,500 $\mu \mathrm{S} / \mathrm{cm}$. The plot also shows that the equation is less accurate and the relation becomes nonlinear when specific conductances are less than $800 \mu \mathrm{S} / \mathrm{cm}$ or greater than $2,500 \mu \mathrm{S} / \mathrm{cm}$. The nonlinear relations are probably caused by concentrations of other dissolved ions in the ground water and also by the greater density of data values in the mid to lower range. This relation is applicable only for samples collected in Orange County. Because specific-conductance measurements can be made easily and inexpensively at the well site, the relation shown can be used to determine approximate concentrations of dissolved chloride. 


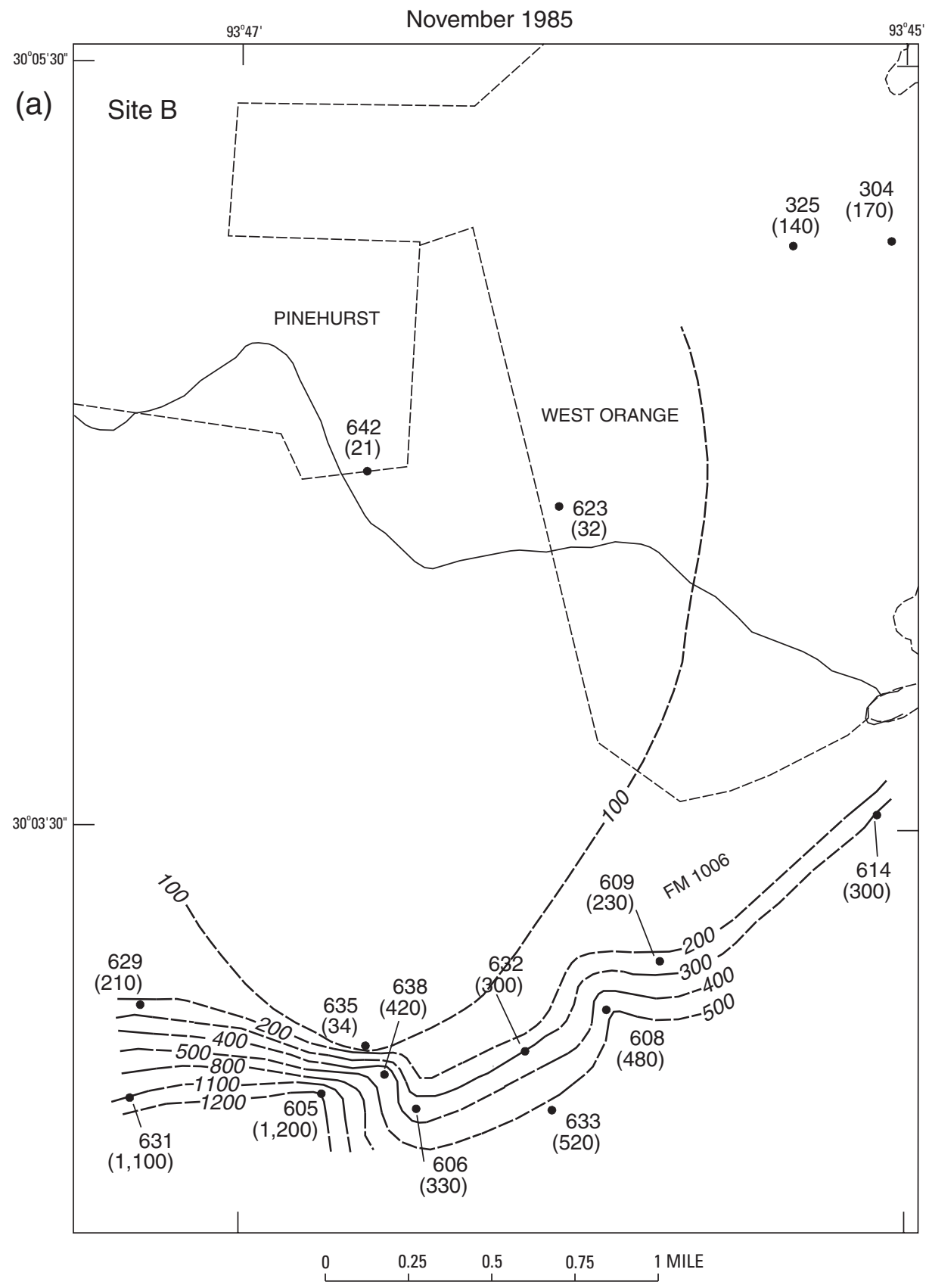

EXPLANATION

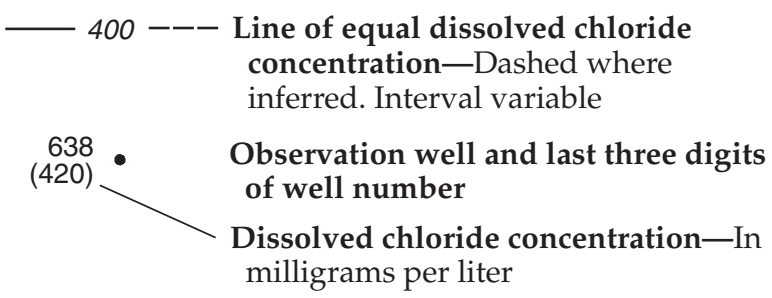

Figure 6. Dissolved chloride concentrations in water from selected wells screened in the lower unit of the Chicot aquifer at Site B in southeastern Orange County, Texas, (a) November 1985, (b) October-November 1986, and (c) October 1988. 


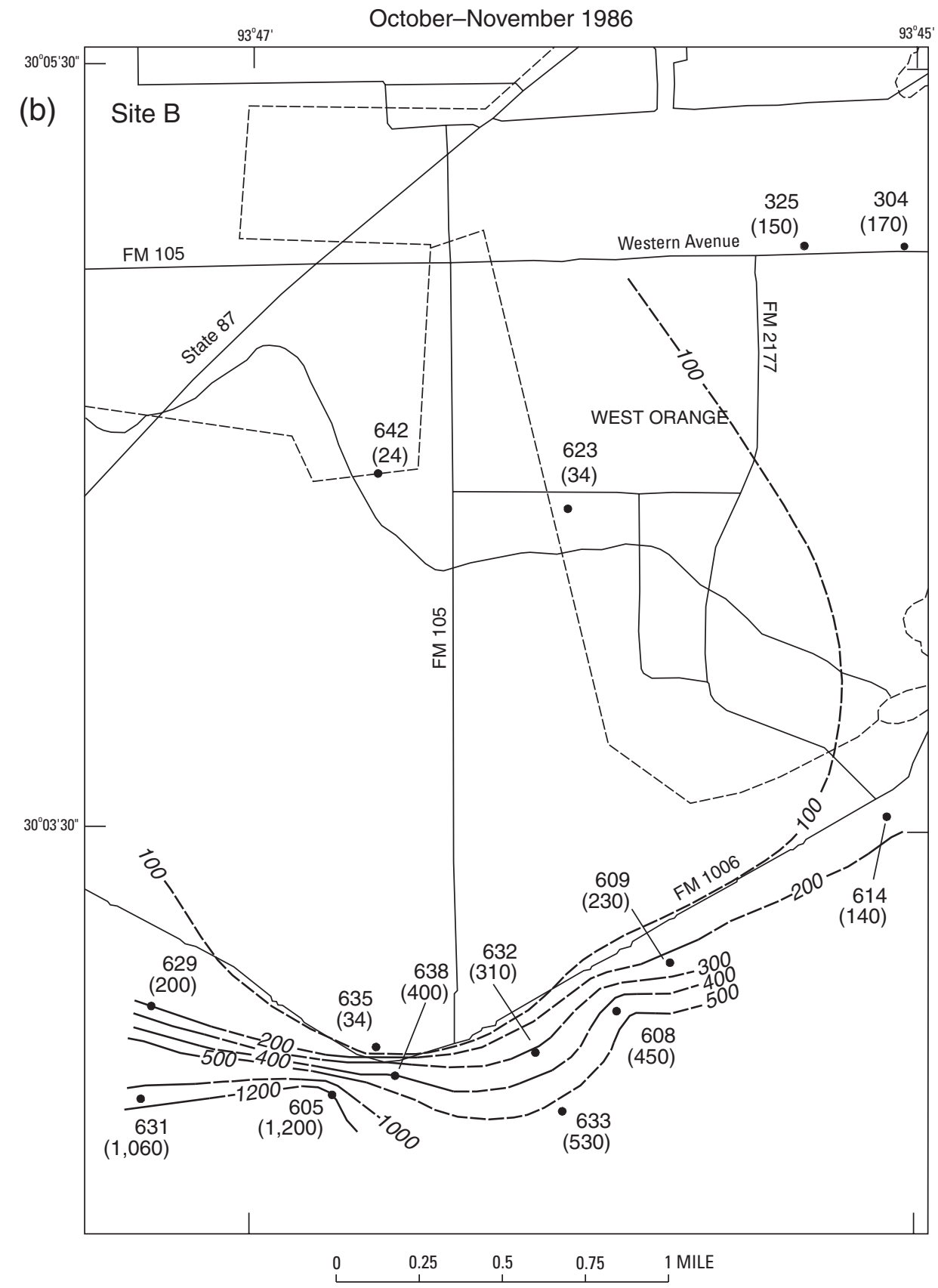

EXPLANATION

Line of equal dissolved chloride
concentration-Dashed where
inferred. Interval variable

Figure 6.-Continued. 


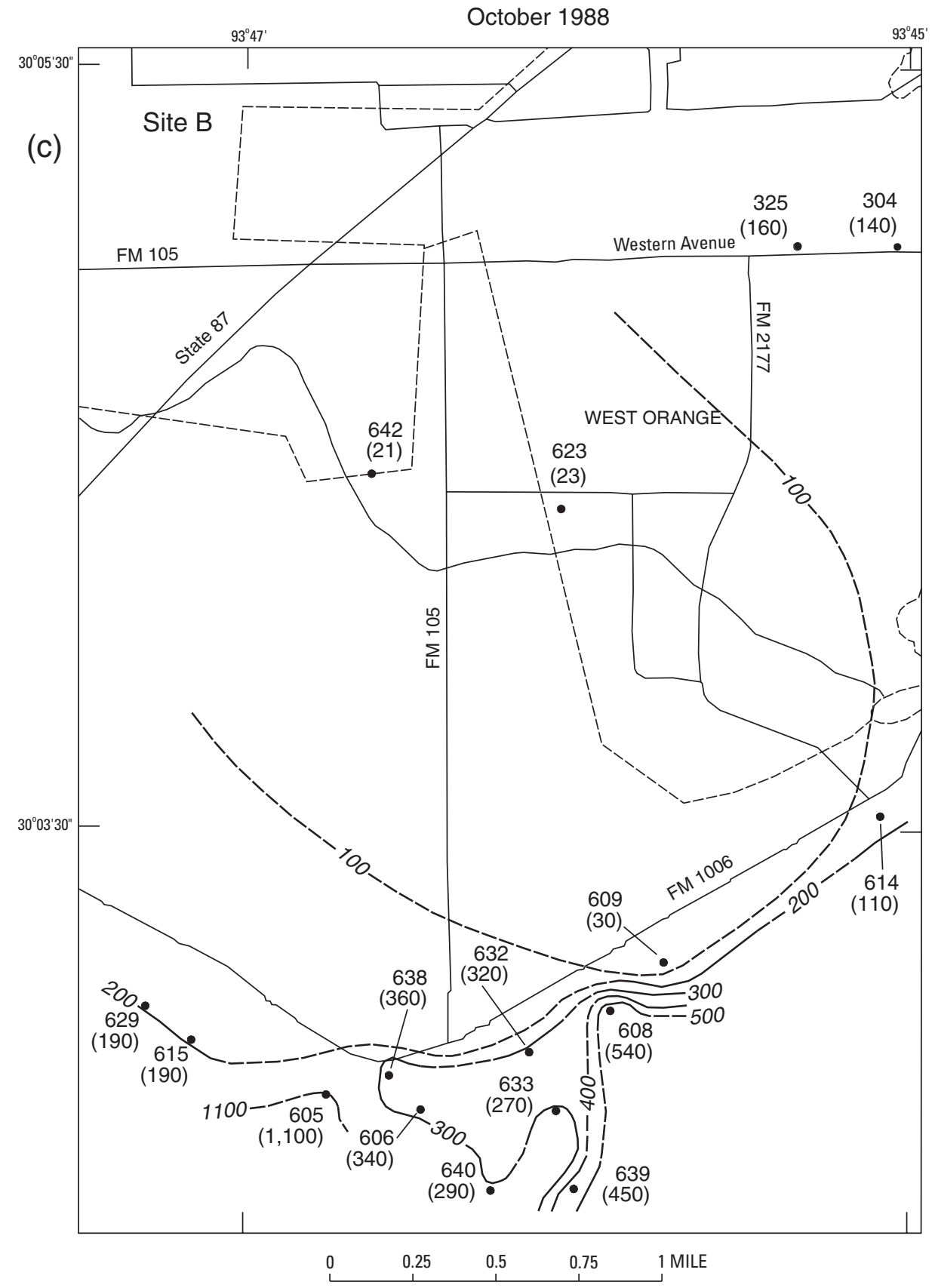

EXPLANATION

--- Line of equal dissolved chloride concentration-Dashed where inferred. Interval, in feet, is variable

Observation well and last three digits of well number

Dissolved chloride concentration-In milligrams per liter

Figure 6.-Continued. 


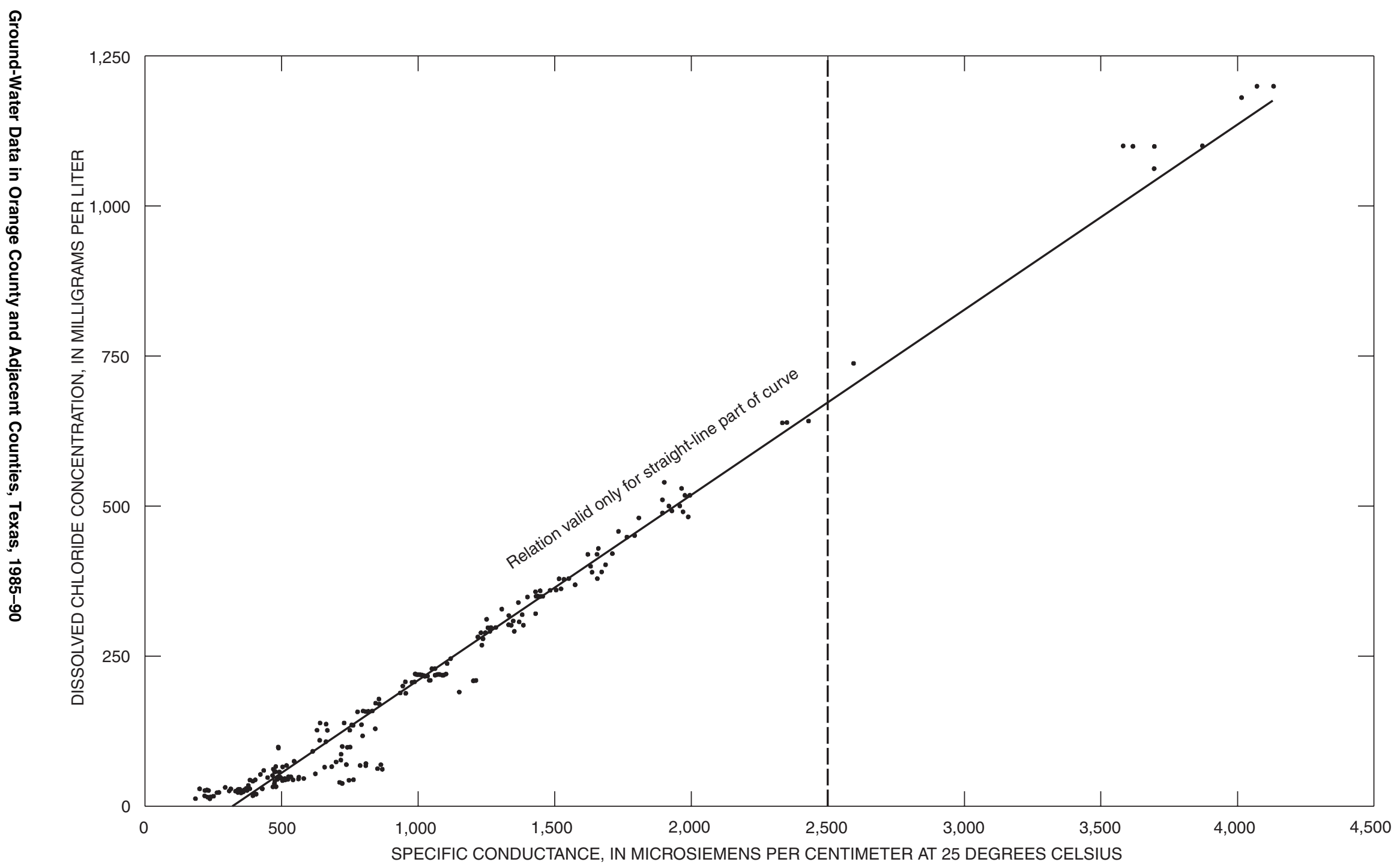

Figure 7. Relation between specific conductance and dissolved chloride concentrations in water from wells screened in the lower unit of the Chicot aquifer, Orange County, Texas, 1985-89. 


\section{SUMMARY}

The lower unit of the Chicot aquifer is a major source of freshwater for Orange County, Texas. The lower unit of the aquifer, separated from the upper unit by clay beds, is Pleistocene in age and underlies all of the study area at varying depths. The altitude of the base of the aquifer ranges from less than $400 \mathrm{ft}$ below sea level in northwestern Orange County to about $1,000 \mathrm{ft}$ below sea level in southeastern Orange County.

In 1989, the average rate of ground-water withdrawals from the lower unit of the Chicot aquifer in Orange County for combined municipal and industrial use was $13.8 \mathrm{Mgal} / \mathrm{d}$, a substantial decrease from the historical high of $23.1 \mathrm{Mgal} / \mathrm{d}$ in 1972 . Average annual withdrawals for municipal and industrial use were similar for $1985-89$, ranging from 13.1 to $14.6 \mathrm{Mgal} / \mathrm{d}$. The average withdrawal for industrial use decreased substantially from $14.4 \mathrm{Mgal} / \mathrm{d}$ during 1963-84 to $6.9 \mathrm{Mgal} / \mathrm{d}$ during 1985-89. The average withdrawal for municipal use during 1985-89 was $6.8 \mathrm{Mgal} / \mathrm{d}$, similar to the average withdrawal of $5.8 \mathrm{Mgal} / \mathrm{d}$ during 1963-84.

Water levels in wells in most of the study area rose during 1985-90 because of decreased groundwater withdrawal associated with declining economic conditions and recycling of some of the water used for industrial purposes during that period. The largest rise in water levels was more than $10 \mathrm{ft}$ in parts of Orange and Pinehurst, north of site $\mathrm{B}$, while the largest decline in water levels was a localized decline of more than 60 $\mathrm{ft}$ at site $\mathrm{C}$ in south-central Orange County.

Chemical analyses of ground-water samples from the lower Chicot aquifer during 1985-90 indicate that the aquifer contained mostly freshwater (dissolved solids concentrations less than 1,000 mg/L). Dissolved chloride concentrations in most wells within the study area remained relatively constant during 1985-90. However, the distribution of dissolved chloride showed that, in some areas, concentrations could vary greatly between wells within short distances. The data also indicate that the saline-water encroachment, primarily by saline-water upconing, continued to occur during 1985-89, but in smaller dissolved chloride concentrations and at a slower rate compared to the 1970s and early 1980s. To mitigate the effects of saline-water encroachment, ground-water users in areas with large rates of ground-water withdrawal and large dissolved chloride concentrations used the following techniques: alternating pumping between available wells; carefully monitoring withdrawal rates, specific conductivities, and dissolved chloride concentrations; supplementing ground-water withdrawals with surface-water pumpage; and recycling the water used for industrial purposes.

On the basis of chemical data collected during 1985-89, a relation was determined between specific conductance and dissolved chloride concentration that can be used to estimate dissolved chloride by multiplying the specific conductance by different factors for low or high conductances.

\section{SELECTED REFERENCES}

Baker, E.T., Jr., 1964, Geology and ground-water resources of Hardin County, Texas: Texas Water Commission Bulletin 6406, 179 p.

Bonnet, C.W., 1975, Ground-water data for Orange County and vicinity, Texas and Louisiana, 1971-74: Texas Water Development Board Report 197, 26 p.

Bonnet, C.W., and Gabrysch, R.K., 1983, Development of ground-water resources in Orange County, Texas, and adjacent areas, 1971-80: Texas Department of Water Resources Report 283, $51 \mathrm{p}$.

Bonnet, C.W., and Williams, J.F., III, 1987, Development of ground-water resources in the Orange County area, Texas and Louisiana, 1980-Spring of 1985: U.S. Geological Survey, Water-Resources Investigations Report $87-4158,50 \mathrm{p}$.

Gabrysch, R.K., and McAdoo, G.D., 1972, Development of ground-water resources in the Orange County area, Texas and Louisiana, 1963-71: Texas Water Development Board Report 156, 47 p.

Harder, A.H., 1960, The geology and ground-water resources of Calcasieu Parish, Louisiana: U.S. Geological Survey Water-Supply Paper 1488, 102 p.

Harder, A.H., Kilbum, C., Whitman, H.M., and Rogers, S.M., 1967, Effects of ground-water withdrawals on water levels and saltwater encroachment in Southwestern Louisiana: Louisiana Department of Conservation and Louisiana Department of Public Works, Water Resources Bulletin 10, 56 p.

Hem, J.D., 1989, Study and interpretation of the chemical characteristics of natural water: U.S. Geological Survey Water-Supply Paper 2254, $263 \mathrm{p}$.

Jones, P.H., Hendricks, E.L., Irelan, Burdge, and others, 1956, Water resources of southwestern Louisiana: U.S. Geological Survey Water-Supply Paper 1364, $460 \mathrm{p}$. 
Jones, P.H., Turcan, A.N., Jr., and Skibitzke, H.E., 1954, Geology and ground-water resources of southwestern Louisiana: Louisiana Geological Survey, Geological Bulletin 30, 285 p.

McAdoo, G.D., 1968, Ground-water data for Orange County and vicinity, Texas and Louisiana, 1968: U.S. Geological Survey Open-File Report, 20 p.

1969, Ground-water data for Orange County and vicinity, Texas and Louisiana, 1969: U.S. Geological Survey Open-File Report, 22 p.

1970, Ground-water data for Orange County and vicinity, Texas and Louisiana, 1970: U.S. Geological Survey Open-File Report, 19 p.

Nyman, D.J., 1984, The occurrence of high concentrations of chloride in the Chicot aquifer system of southwestern Louisiana: Louisiana Department of Transportation and Development, Water Resources Technical Report 33, $75 \mathrm{p}$.

Ratzlaff, K.W., 1980, Land-surface subsidence in the Texas coastal region: U.S. Geological Survey Open-File Report 80-969, 19 p.

Texas Water Commission, 1986, Texas Superfund Notebook, A Briefing on National Priority List Sites in Texas: Texas Water Commission Report LP 86-02, 150 p.

Turcan, A.N., Jr., Wesselman, J.B., and Kilburn, Chabot, 1966, Interstate correlation of aquifers, southwestern Louisiana and southeastern Texas: U.S. Geological Survey Professional Paper 550-D, p. D231-D236.

\section{GLOSSARY}

Aquifer-A formation, group of formations, or part of a formation that contains sufficient saturated permeable material to yield substantial quantities of water to wells and springs.

Confining unit - A body of markedly less permeable material, stratigraphically adjacent to one or more aquifers, that confines water in the aquifer so that the water level rises above the base of the confining unit.

Freshwater-Variously defined as water containing less than $1,000 \mathrm{mg} / \mathrm{L}$ dissolved solids or water containing $250 \mathrm{mg} / \mathrm{L}$ or less dissolved chloride. In this report, freshwater is defined as water having a dissolved solids concentration of $250 \mathrm{mg} / \mathrm{L}$ or less.

Freshwater/saline-water interface-The boundary surface between two fluids of different density; the boundary is the sloping surface between freshwater and saline water in this report.
U.S. Environmental Protection Agency, 1996, Drinking water regulations and health advisories: Washington, D.C., U.S. Environmental Protection Agency, 11 p.

Wesselman, J.B., 1965, Geology and ground-water resources of Orange County, Texas: Texas Water Commission Bulletin 6516, $112 \mathrm{p}$.

1967, Ground-water resources of Jasper and Newton Counties, Texas: Texas Water Development Board Report 59, $186 \mathrm{p}$.

1971, Ground-water resources of Chambers and Jefferson Counties, Texas, with a section on Quaternary geology, by Saul Aronow: Texas Water Development Board Report 133, 183 p.

Winslow, A.G., and Kister, L.R., 1956, Saline-water resources of Texas: U.S. Geological Survey WaterSupply Paper 1365, 105 p.

Winslow, A.G., and Wood, L.A., Relation of land subsidence to ground-water withdrawals in the upper Gulf Coast region, Texas: Mining Engineering, v. 11, no. 10, p. $1,030-1,034$.

Wood, L.A., and Gabrysch, R.K., 1965, Analog model study of ground water in the Houston district, Texas, with a section on Design, construction, and use of electric analog models, by E.P. Patton, Jr.: Texas Water Commission Bulletin 6508, 103 p.

Zack, A.L., 1971, Ground-water pumpage and related effects, southwestern Louisiana, 1970, with a section on Surface-water withdrawals: Louisiana Department of Conservation and Louisiana Department of Public Works, Water Resources Pamphlet 27, 35 p.

Saline water-Water with a dissolved solids concentration equal to or greater than $1,000 \mathrm{mg} / \mathrm{L}$. Four classes of saline water have been defined by Winslow and Kister (1956) according to the concentrations of dissolved solids: (1) slightly saline, 1,000 to $3,000 \mathrm{mg} / \mathrm{L}$; (2) moderately saline, 3,000 to $10,000 \mathrm{mg} / \mathrm{L}$; (3) very saline, 10,000 to $35,000 \mathrm{mg} / \mathrm{L}$; and (4) brine, greater than $35,000 \mathrm{mg} / \mathrm{L}$.

Saline-water upconing (or vertical intrusion) - A phenomenon caused when two fluids with different densities at dynamic equilibrium are made dynamically unstable by withdrawal by pumping of the upper or less dense fluid.

Saline-water encroachment (or intrusion) - The phenomenon occurring when a body of saline water, because of its greater density or hydraulic head, encroaches (or intrudes) into a body of freshwater. 
Table 1. Hydrogeologic correlations for Orange County and adjacent counties, Texas

[Modified from Nyman (1984, table 1)]

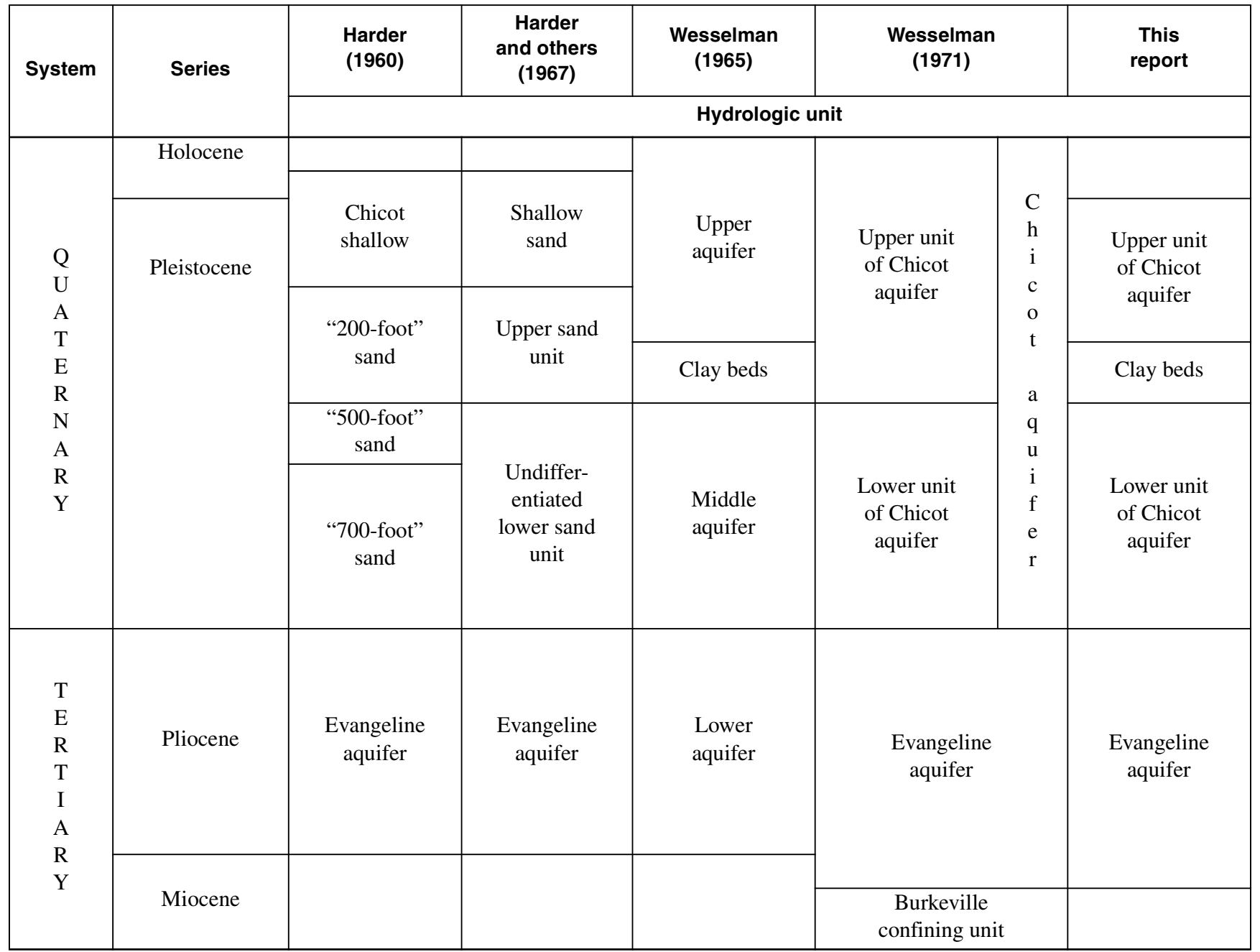

Table 2. Average daily rates of ground-water withdrawals for municipal and industrial use from the lower unit of the Chicot aquifer in Orange County, Texas, 1980-89, in million gallons per day

[Data for 1980-84 from Bonnet and Williams, 1987]

\begin{tabular}{cccc}
\hline Year & Municipal use & Industrial use & Total use \\
\hline 1980 & 7.5 & 12.2 & 19.7 \\
1981 & 7.3 & 12.8 & 20.1 \\
1982 & 7.4 & 10.3 & 17.7 \\
1983 & 7.2 & 8.9 & 16.1 \\
1984 & 7.0 & 8.2 & 15.2 \\
1985 & 6.7 & 6.4 & 13.1 \\
1986 & 6.5 & 6.7 & 13.2 \\
1987 & 6.4 & 7.2 & 13.6 \\
1988 & 7.1 & 7.5 & 14.6 \\
1989 & 7.1 & 6.7 & 13.8 \\
\hline
\end{tabular}


Table 3. Average daily rates of ground-water withdrawals from the lower unit of the Chicot aquifer at major industrial sites in Orange County, Texas, 1980-89, in million gallons per day

[Data for 1980-84 from Bonnet and Williams, 1987]

\begin{tabular}{ccccc}
\hline Year & Site A & Site B & Site C & Total \\
\hline 1980 & 3.9 & 6.4 & 1.9 & 12.2 \\
1981 & 4.2 & 6.4 & 2.2 & 12.8 \\
1982 & 3.4 & 4.7 & 2.2 & 10.3 \\
1983 & 2.2 & 4.5 & 2.2 & 8.9 \\
1984 & 1.4 & 4.9 & 1.9 & 8.2 \\
1985 & .5 & 3.8 & 1.2 & 5.5 \\
1986 & .5 & 3.6 & 1.5 & 5.6 \\
1987 & .6 & 3.8 & 1.7 & 6.1 \\
1988 & .7 & 4.0 & 1.5 & 6.2 \\
1989 & .7 & 3.8 & 1.3 & 5.8 \\
\hline
\end{tabular}

Table 4. Average daily rates of surface water supplied for municipal and industrial use in Orange County, Texas, 1980-89, in million gallons per day

[Data tabulated by Bill Moltz, Texas Water Development Board. --, data not available]

\begin{tabular}{lccc}
\hline Year & Municipal & Industrial & Total \\
\hline 1980 & -- & -- & 48.6 \\
1981 & -- & -- & 58.1 \\
1982 & -- & -- & 38.0 \\
1983 & -- & -- & 36.5 \\
1984 & -- & -- & 41.4 \\
1985 & 0.1 & 37.1 & 37.2 \\
1986 & .1 & 39.4 & 39.5 \\
1987 & .1 & 42.3 & 42.4 \\
1988 & .1 & 46.5 & 46.6 \\
1989 & .1 & 45.1 & 45.2 \\
\hline
\end{tabular}

Table 5. Average daily rates of ground-water withdrawals from the Evangeline aquifer and lower unit of the Chicot aquifer for public supply in eastern Jefferson, eastern Hardin, and southern Jasper Counties, Texas, 1985-89, in million gallons per day

[Data tabulated by Bill Moltz, Texas Water Development Board]

\begin{tabular}{lrrrrr}
\hline \multicolumn{1}{c}{ User } & $\mathbf{1 9 8 5}$ & $\mathbf{1 9 8 6}$ & $\mathbf{1 9 8 7}$ & $\mathbf{1 9 8 8}$ & $\mathbf{1 9 8 9}$ \\
\hline Beaumont, Jefferson County & 9.8 & 8.4 & 7.3 & 7.2 & 7.0 \\
Silsbee, Hardin County & 1.0 & .9 & .9 & .9 & 1.0 \\
Lumberton Municipal Utility District, Hardin County & .9 & .8 & .8 & .9 & .9 \\
Buna, Jasper County & .2 & .2 & .3 & .3 & .3 \\
Evadale, Jasper County & .1 & .3 & .1 & .1 & .1 \\
Totals: & 12.0 & 10.6 & 9.4 & 9.4 & 9.3 \\
\hline
\end{tabular}


Table 6. Water levels in observation wells in Orange County and adjacent counties, Texas, 1985-90

Owner : WCID, Water Control and Improvement District; CSD, Consolidated School District; Util., Utility;

ISD, Independent School District; MUD, Municipal Utility District

Depth : Total depth of well

Screen : Top and bottom of screened interval

Altitude : Altitude of land surface datum above sea level

Water level: Feet below land surface

Orange County

Well UJ-61-56-103

Owner: B.H. Thibodeau

Depth: 76 feet

Altitude: 23 feet

\begin{tabular}{cc}
\hline Date & Water level \\
\hline $04-15-85$ & 11.09 \\
$04-28-86$ & 12.15 \\
$05-11-87$ & 11.08 \\
$04-11-88$ & 11.61 \\
$05-31-89$ & 11.43 \\
$11-27-89$ & 14.18 \\
$04-16-90$ & 11.68 \\
\hline
\end{tabular}

Well UJ-61-56-314

Owner: G.C. Hinch

Screen: $375-385$ feet

Altitude: 27 feet

\begin{tabular}{cc}
\hline Date & Water level \\
\hline $04-15-85$ & 44.20 \\
$04-28-86$ & 43.84 \\
$04-22-87$ & 42.77 \\
$04-11-88$ & 42.34 \\
$05-31-89$ & 42.16 \\
$11-27-89$ & 43.00 \\
$04-16-90$ & 41.47 \\
\hline
\end{tabular}

\section{Well UJ-61-56-315}

Owner: Iwanda Trailer Park

Screen: $356-380$ feet

Altitude: 26 feet

\begin{tabular}{cc}
\hline Date & Water level \\
\hline $04-15-85$ & 44.37 \\
$04-28-86$ & 44.20 \\
$04-22-87$ & 42.31 \\
$04-11-88$ & 41.88 \\
$05-31-89$ & 41.52 \\
$04-17-90$ & 42.19 \\
\hline
\end{tabular}

Well UJ-61-56-611

Owner: Larry Brewer

Screen: 441-457 feet

Altitude: 22 feet

\begin{tabular}{cc}
\hline Date & Water level \\
\hline $04-18-90$ & 46.90 \\
\hline
\end{tabular}

Well UJ-61-56-901

Owner: Orange County WCID 1 , well 2

Screen: $350-400$ feet

Altitude: 21 feet

\begin{tabular}{cc}
\hline Date & Water level \\
\hline $04-09-85$ & 50.65 \\
$05-02-86$ & 47.42 \\
$05-11-87$ & 46.24 \\
$04-18-88$ & 47.28 \\
$05-31-89$ & 46.76 \\
$04-17-90$ & 45.73 \\
\hline
\end{tabular}

\section{Well UJ-61-56-911}

Owner: Community Water System

Screen: 468-486 feet

Altitude: 12 feet

\begin{tabular}{cc}
\hline Date & Water level \\
\hline $04-18-90$ & 37.94 \\
\hline
\end{tabular}

Well UJ-61-56-919

Owner: Orange County WCID 1 , well 3

Screen: $385-420$ feet

Altitude: 21 feet

\begin{tabular}{cc}
\hline Date & Water level \\
\hline $04-09-85$ & 49.84 \\
$05-01-86$ & 49.73 \\
$05-11-87$ & 49.06 \\
$04-18-88$ & 49.76 \\
$05-31-89$ & 49.15 \\
$04-17-90$ & 46.66 \\
\hline
\end{tabular}

Well UJ-61-56-920

Owner: Orange County WCID 1, Wexford Park

Depth: 380 feet

Altitude: 11 feet

\begin{tabular}{cc}
\hline Date & Water level \\
\hline $04-15-85$ & 47.54 \\
$05-02-86$ & 48.87 \\
$04-22-87$ & 45.64 \\
$05-31-89$ & 44.30 \\
$04-18-90$ & 45.92 \\
\hline
\end{tabular}

Well UJ-61-56-922

Owner: Orange County WCID 1 , well 4

Screen: $284-490$ feet

Altitude: 26 feet

\begin{tabular}{cc}
\hline Date & Water level \\
\hline $04-09-85$ & 58.24 \\
$04-17-90$ & 51.09 \\
\hline
\end{tabular}

Well UJ-61-56-923

Owner: Orange County WCID 1, Tiger Lake

Screen: $430-460$ feet

Altitude: 16 feet

\begin{tabular}{cc}
\hline Date & Water level \\
\hline $04-18-90$ & 45.33 \\
\hline
\end{tabular}

Well UJ-62-49-503

Owner: G.L. Linscomb

Depth: 117 feet

Altitude: 26 feet

\begin{tabular}{cc}
\hline Date & Water level \\
\hline $04-08-85$ & 8.74 \\
$04-29-86$ & 11.16 \\
$04-22-87$ & 9.46 \\
$04-18-88$ & 9.41 \\
$05-31-89$ & 8.98 \\
$04-17-90$ & 9.23 \\
\hline
\end{tabular}


Table 6. Water levels in observation wells in Orange County and adjacent counties, Texas, 1985-90—Continued

Well UJ-62-49-804

Owner: Parkview Subdivision

Screen: 470-490 feet

Altitude: 14 feet

\begin{tabular}{cc}
\hline Date & Water level \\
\hline $04-17-90$ & 38.55 \\
\hline
\end{tabular}

Well UJ-62-49-904

Owner: Texas Department of Transportation

Screen: $399-415$ feet

Altitude: 16 feet

\begin{tabular}{cc}
\hline Date & Water level \\
\hline $04-30-86$ & 39.45 \\
$05-12-87$ & 38.75 \\
$04-18-90$ & 37.75 \\
\hline
\end{tabular}

Well UJ-62-50-107

Owner: Mauriceville Water Supply

Corp., well 4

Screen: $680-730$ feet

Altitude: 26 feet

\begin{tabular}{cc}
\hline Date & Water level \\
\hline $04-28-90$ & ${ }^{1} 38$ \\
\hline${ }^{1}$ Reported by well
\end{tabular}

Well UJ-62-50-201

Owner: Boyce N. Ward

Screen: 476-586 feet

Altitude: 26 feet

\begin{tabular}{cc}
\hline Date & Water level \\
\hline $04-08-85$ & 44.12 \\
$04-29-86$ & 43.36 \\
$04-22-87$ & 40.02 \\
$04-18-88$ & 41.62 \\
$05-31-89$ & 41.24 \\
$04-18-90$ & 45.03 \\
\hline
\end{tabular}

Well UJ-62-50-807

Owner: Henry L. Wilson

Screen: 442-454 feet

Altitude: 20 feet

\begin{tabular}{cc}
\hline Date & Water level \\
\hline $04-09-85$ & 46.60 \\
$05-05-86$ & 46.37 \\
$05-13-87$ & 43.65 \\
$04-19-88$ & 42.86 \\
$05-31-89$ & 42.52 \\
$04-18-90$ & 42.65 \\
\hline
\end{tabular}

Well UJ-62-50-808

Owner: H.D. Womack

Screen: 643-655 feet

Altitude: 20 feet

\begin{tabular}{cc}
\hline Date & Water level \\
\hline $04-09-85$ & 48.15 \\
$05-05-86$ & 47.31 \\
$05-13-87$ & 46.36 \\
$04-19-88$ & 45.11 \\
$05-31-89$ & 44.55 \\
$04-18-90$ & 45.40 \\
\hline
\end{tabular}

Well UJ-62-50-911

Owner: City of Orange, well 9

Screen: 454-618 feet

Altitude: 12 feet

\begin{tabular}{cc}
\hline Date & Water level \\
\hline $04-10-85$ & 44.10 \\
$04-21-87$ & 40.56 \\
$04-23-90$ & 41.97 \\
\hline
\end{tabular}

Well UJ-62-50-912

Owner: Little Cypress-Mauriceville CSD

Screen: 460-510 feet

Altitude: 16 feet

\begin{tabular}{cc}
\hline Date & Water level \\
\hline $05-12-87$ & 48.0 \\
\hline
\end{tabular}

Well UJ-62-51-103

Owner: Inland-Orange Inc.

Screen: 445-515 feet

Altitude: 25 feet

\begin{tabular}{cc}
\hline Date & Water level \\
\hline $04-09-85$ & 40.71 \\
$05-08-86$ & 41.15 \\
$05-13-87$ & 42.28 \\
$04-18-88$ & 39.25 \\
$06-05-89$ & 37.52 \\
$04-18-90$ & 39.04
\end{tabular}

Well UJ-62-51-104

Owner: Inland-Orange Inc.

Screen: 460-470 feet

Altitude: 24 feet

\begin{tabular}{cc}
\hline Date & Water level \\
\hline $04-18-90$ & 41.54 \\
\hline
\end{tabular}

Well UJ-62-51-707

Owner: J.M. Huber Co.

Screen: 428-488 feet

Altitude: 12 feet

\begin{tabular}{cc}
\hline Date & Water level \\
\hline $04-09-85$ & 46.52 \\
$05-08-86$ & 42.70 \\
$04-22-87$ & 44.42 \\
$04-18-88$ & 42.08 \\
$06-06-89$ & 39.74 \\
$04-19-90$ & 42.29 \\
\hline
\end{tabular}

Well UJ-62-57-203

Owner: Joe M. Heinen

Depth: 740 feet

Altitude: 18 feet

\begin{tabular}{cc}
\hline Date & Water level \\
\hline $04-09-85$ & 45.31 \\
$05-02-86$ & 46.43 \\
$04-21-87$ & 45.87 \\
$04-12-88$ & 45.46 \\
$06-06-89$ & 45.02 \\
$04-18-90$ & 42.33 \\
\hline
\end{tabular}

Well UJ-62-57-401

Owner: Texas Eastern Gas Pipeline Co.

Screen: 448-468 feet

Altitude: 16 feet

\begin{tabular}{cc}
\hline Date & Water level \\
\hline $04-11-85$ & 48.84 \\
$04-30-86$ & 43.09 \\
$05-14-87$ & 44.80 \\
$04-13-88$ & 45.22 \\
$06-06-89$ & 44.55 \\
$04-19-90$ & 40.91 \\
\hline
\end{tabular}

Well UJ-62-57-403

Owner: Gulf States Util. Co., Vidor, well 1

Screen: 433-483 feet

Altitude: 15 feet

\begin{tabular}{cc}
\hline Date & Water level \\
\hline $04-09-85$ & 42.89 \\
$04-29-86$ & 43.14 \\
$04-12-88$ & 41.30 \\
$06-02-89$ & 39.95 \\
$04-20-90$ & 40.53 \\
\hline
\end{tabular}


Table 6. Water levels in observation wells in Orange County and adjacent counties, Texas, 1985-90-Continued

Well UJ-62-57-404

Owner: Gulf States Util. Co., Vidor, well 2

Screen: $430-481$ feet

Altitude: 16 feet

\begin{tabular}{cc}
\hline Date & Water level \\
\hline $04-09-85$ & 44.90 \\
$04-20-87$ & 41.04 \\
$04-12-88$ & 40.88 \\
$06-02-89$ & 40.82 \\
$04-19-90$ & 42.14
\end{tabular}

Well UJ-62-57-405

Owner: Gulf States Util. Co., Vidor, well 3

Screen: $430-480$ feet

Altitude: 18 feet

\begin{tabular}{cc}
\hline Date & Water level \\
\hline $04-09-85$ & 46.20 \\
$04-29-86$ & 44.84 \\
$04-20-87$ & 43.78 \\
$04-12-88$ & 44.81 \\
$06-02-89$ & 39.70 \\
$04-19-90$ & 42.14
\end{tabular}

Well UJ-62-57-406

Owner: Gulf States Util. Co., Vidor, well 6

Screen: $430-480$ feet

Altitude: 15 feet

\begin{tabular}{cc}
\hline Date & Water level \\
\hline $04-09-85$ & 44.82 \\
$04-29-86$ & 41.43 \\
$04-20-87$ & 38.85 \\
$11-22-89$ & 35.40 \\
$04-19-90$ & 35.93 \\
\hline
\end{tabular}

Well UJ-62-57-407

Owner: Gulf States Util. Co., Vidor, well 4

Screen: $320-370$ feet

Altitude: 6 feet

\begin{tabular}{cc}
\hline Date & Water level \\
\hline $04-09-85$ & 30.60 \\
$04-29-86$ & 27.30 \\
$04-20-87$ & 21.58 \\
$06-02-89$ & 4.69 \\
$04-19-90$ & 3.84 \\
\hline
\end{tabular}

\section{Well UJ-62-57-408}

Owner: Gulf States Util. Co., Vidor, well 5

Screen: $343-383$ feet

Altitude: 6 feet

\begin{tabular}{cc}
\hline Date & Water level \\
\hline $04-09-85$ & 31.36 \\
$04-29-86$ & 27.93 \\
$04-20-87$ & 25.59 \\
$04-12-88$ & 24.69 \\
$06-02-89$ & 22.23 \\
$04-19-90$ & 26.22 \\
\hline
\end{tabular}

Well UJ-62-57-409

Owner: Ted B. Michael

Screen: 550-640 feet

Altitude: 13 feet

\begin{tabular}{cc}
\hline Date & Water level \\
\hline $04-09-85$ & 43.05 \\
$04-29-86$ & 42.54 \\
$05-14-87$ & 41.68 \\
$04-12-88$ & 42.65 \\
$06-02-89$ & 41.07 \\
$04-20-90$ & 40.40
\end{tabular}

Well UJ-62-57-501

Owner: Enron Gas Pipeline Operating Co.

Screen: 405-435 feet

Altitude: 16 feet

\begin{tabular}{cc}
\hline Date & Water level \\
\hline $04-09-85$ & 41.60 \\
$05-02-86$ & 40.24 \\
$04-21-87$ & 41.14 \\
$04-12-88$ & 40.17 \\
$06-02-89$ & 38.81 \\
\hline
\end{tabular}

Well UJ-62-57-904

Owner: Gulf States Util. Co., Sabine, well 4

Screen: 432-455 feet

Altitude: 10 feet

\begin{tabular}{cc}
\hline Date & Water level \\
\hline $05-13-87$ & 88.23 \\
$04-20-90$ & 97.65 \\
\hline
\end{tabular}

Well UJ-62-57-905

Owner: Gulf States Util. Co., Sabine, well 5

Screen: 422-461 feet

Altitude: 8 feet

\begin{tabular}{cc}
\hline Date & Water level \\
\hline 04-20-90 & 98.46 \\
\hline
\end{tabular}

Well UJ-62-57-907

Owner: Gulf States Util. Co., Sabine, well 7

Screen: 604-654 feet

Altitude: 10 feet

\begin{tabular}{cc}
\hline Date & Water level \\
\hline $05-13-87$ & 46.76 \\
$04-20-90$ & 37.30 \\
\hline
\end{tabular}

Well UJ-62-57-908

Owner: Gulf States Util. Co., Sabine, well 8

Screen: 573-623 feet

Altitude: 10 feet

\begin{tabular}{cc}
\hline Date & Water level \\
\hline $04-16-85$ & 41.25 \\
$05-08-86$ & 41.11 \\
$04-20-90$ & 35.72 \\
\hline
\end{tabular}

Well UJ-62-57-909

Owner: Gulf States Util. Co., Sabine, well 9

Screen: $410-460$ feet

Altitude: 10 feet

\begin{tabular}{cc}
\hline Date & Water level \\
\hline $04-20-90$ & 106.42 \\
\hline
\end{tabular}

Well UJ-62-58-208

Owner: J.M. Huber Plastics, well 2

Screen: 509-539 feet

Altitude: 14 feet

\begin{tabular}{cc}
\hline Date & Water level \\
\hline $07-01-89$ & 150 \\
\hline${ }^{1}$ Reported by well owner.
\end{tabular}


Table 6. Water levels in observation wells in Orange County and adjacent counties, Texas, 1985-90—Continued

Well UJ-62-58-304

Owner: Orange County WCID 2, well 1

Screen: 626-706 feet

Altitude: 10 feet

\begin{tabular}{cc}
\hline Date & Water level \\
\hline $04-10-85$ & 47.70 \\
$04-30-86$ & 41.33 \\
$04-21-87$ & 49.14 \\
$04-12-88$ & 47.62 \\
$04-23-90$ & 47.38 \\
\hline
\end{tabular}

Well UJ-62-58-305

Owner: City of Orange, well 8

Screen: 520-610 feet

Altitude: 11 feet

\begin{tabular}{cc}
\hline Date & Water level \\
\hline $04-10-85$ & 51.36 \\
$05-01-86$ & 44.31 \\
$04-21-87$ & 46.11 \\
$04-21-88$ & 43.72 \\
$06-05-89$ & 41.13 \\
$04-23-90$ & 43.93 \\
\hline
\end{tabular}

Well UJ-62-58-324

Owner: City of Pinehurst, well 1

Screen: 365-445 feet

Altitude: 14 feet

\begin{tabular}{cc}
\hline Date & Water level \\
\hline $04-10-85$ & 56.73 \\
$05-01-86$ & 52.12 \\
$05-14-87$ & 44.58 \\
$04-21-88$ & 43.15 \\
$06-05-89$ & 41.60 \\
$04-24-90$ & 46.24 \\
\hline
\end{tabular}

Well UJ-62-58-325

Owner: Orange County WCID 2, well 2

Screen: 620-670 feet

Altitude: 12 feet

\begin{tabular}{cc}
\hline Date & Water level \\
\hline $04-10-85$ & 44.97 \\
$04-30-86$ & 47.18 \\
$04-21-87$ & 51.78 \\
$04-12-88$ & 49.25 \\
$06-05-89$ & 47.40 \\
$04-23-90$ & 45.03 \\
\hline
\end{tabular}

Well UJ-62-58-326

Owner: City of Pinehurst, well 2

Screen: 530-600 feet

Altitude: 14 feet

\begin{tabular}{cc}
\hline Date & Water level \\
\hline 04-24-90 & 45.10 \\
\hline Well UJ-62-58-403 \\
Owner: Orangefield ISD \\
Screen: 460-480 feet \\
Altitude: 15 feet \\
\hline \multicolumn{2}{c}{ Date } \\
\hline 04-09-85 \\
04-30-86 \\
04-20-87 \\
04-12-88 & 43.03 \\
06-05-89 & 43.48 \\
04-24-90 & 43.70 \\
\end{tabular}

Well UJ-62-58-410

Owner: Orangefield Recreation Park

Screen: $110-120$ feet

Altitude: 5 feet

\begin{tabular}{cc}
\hline Date & Water level \\
\hline $04-09-85$ & 7.70 \\
$04-30-86$ & 4.14 \\
$04-20-87$ & 4.02 \\
$04-12-88$ & 3.07 \\
$04-24-90$ & 3.24 \\
\hline
\end{tabular}

Well UJ-62-58-514

Owner: Doan's Nursery

Depth: 400 feet

Altitude: 8 feet

\begin{tabular}{cc}
\hline Date & Water level \\
\hline 04-19-90 & 7.44 \\
\hline
\end{tabular}

Well UJ-62-58-515

Owner: Doan's Nursery

Depth: 275 feet

Altitude: 8 feet

\begin{tabular}{cc}
\hline Date & Water level \\
\hline 04-19-90 & 10.20 \\
\hline
\end{tabular}

Well UJ-62-58-602

Owner: Ernest H. Willey

Depth: 711 feet

Altitude: 14 feet

\begin{tabular}{cc}
\hline Date & Water level \\
\hline $04-10-85$ & 50.10 \\
$04-30-86$ & 47.97 \\
$05-12-87$ & 48.15 \\
$04-12-88$ & 40.65 \\
$05-31-89$ & 40.38 \\
$04-24-90$ & 12.51 \\
\hline
\end{tabular}

Well UJ-62-58-603

Owner: W.H. Stark Estate

Depth: 204 feet

Altitude: 8 feet

\begin{tabular}{cc}
\hline Date & Water level \\
\hline $04-10-85$ & 10.53 \\
$05-05-86$ & 10.57 \\
$05-12-87$ & 11.12 \\
$04-13-88$ & 9.71 \\
$05-31-89$ & 9.90 \\
$04-24-90$ & 9.57 \\
\hline
\end{tabular}

Well UJ-62-58-605

Owner: Chevron Chemical Co., well 4 Screen: 604-717 feet

Altitude: 7 feet

\begin{tabular}{cc}
\hline Date & Water level \\
\hline $04-11-85$ & 51.88 \\
$04-25-90$ & 49.99 \\
\hline
\end{tabular}

Well UJ-62-58-606

Owner: James River Corp., well 3

Screen: 630-710 feet

Altitude: 7 feet

\begin{tabular}{cc}
\hline Date & Water level \\
\hline 04-24-90 & 42.90 \\
\hline
\end{tabular}

Well UJ-62-58-608

Owner: Allied-Signal Inc.

Screen: $620-735$ feet

Altitude: 8 feet

\begin{tabular}{cc}
\hline Date & Water level \\
\hline $04-10-85$ & 47.00 \\
$04-30-86$ & 43.48 \\
$04-21-87$ & 51.60 \\
$04-12-88$ & 44.53 \\
$05-31-89$ & 43.14 \\
$04-24-90$ & 45.74 \\
\hline
\end{tabular}


Table 6. Water levels in observation wells in Orange County and adjacent counties, Texas, 1985-90-Continued

Well UJ-62-58-609

Owner: E.I. DuPont Co., well 103-3

Screen: 634-723 feet

Altitude: 11 feet

\begin{tabular}{cc}
\hline Date & Water level \\
\hline $04-12-85$ & 47.35 \\
$05-06-86$ & 45.14 \\
$05-12-87$ & 45.92 \\
$04-19-88$ & 46.11 \\
$06-01-89$ & 45.10 \\
$04-24-90$ & 46.40 \\
\hline
\end{tabular}

\section{Well UJ-62-58-610}

Owner: E.I. DuPont Co., well 103-3.1

Depth: 715 feet

Altitude: 7 feet

\begin{tabular}{cc}
\hline Date & Water level \\
\hline $04-12-85$ & 48.02 \\
$05-06-86$ & 46.67 \\
$05-12-87$ & 46.35 \\
$04-19-88$ & 45.19 \\
$06-01-89$ & 45.33 \\
$04-24-90$ & 45.60 \\
\hline
\end{tabular}

Well UJ-62-58-611 (equipped with A-35 graphic recorder)

Owner: E.I. DuPont Co., well 103-2

Depth: 715 feet

Altitude: 8 feet

\begin{tabular}{cc}
\hline Date & Water level \\
\hline $02-20-85$ & 46.95 \\
$04-08-85$ & 47.22 \\
$11-04-85$ & 46.76 \\
$02-27-86$ & 45.81 \\
$05-08-86$ & 45.00 \\
$08-20-86$ & 45.20 \\
$10-28-86$ & 46.71 \\
$03-25-87$ & 45.20 \\
$05-12-87$ & 45.12 \\
$08-05-87$ & 46.56 \\
$04-12-88$ & 44.90 \\
$10-25-88$ & 46.00 \\
$06-01-89$ & 45.09 \\
$11-22-89$ & 45.49 \\
$04-24-90$ & 45.48 \\
\hline
\end{tabular}

Well UJ-62-58-613

Owner: E.I. DuPont Co., well 103-1.1

Depth: 723 feet

Altitude: 10 feet

\begin{tabular}{cc}
\hline Date & Water level \\
\hline $04-12-85$ & 47.17 \\
$05-06-86$ & 44.88 \\
$05-12-87$ & 45.13 \\
$04-19-88$ & 45.55 \\
$06-01-89$ & 36.70 \\
$04-24-90$ & 45.55 \\
\hline
\end{tabular}

\section{Well UJ-62-58-614}

Owner: E.I. DuPont Co., well 103-1

Depth: 726 feet

Altitude: 11 feet

\begin{tabular}{cc}
\hline Date & Water level \\
\hline $04-12-85$ & 49.39 \\
$05-06-86$ & 47.04 \\
$05-12-87$ & 46.16 \\
$06-01-89$ & 47.61 \\
$04-24-90$ & 47.72 \\
\hline
\end{tabular}

\section{Well UJ-62-58-615}

Owner: Firestone Petrochemical Center, well P-817

Screen: 611-700 feet

Altitude: 9 feet

\begin{tabular}{cc}
\hline Date & Water level \\
\hline $04-10-85$ & 45.63 \\
$04-30-86$ & 45.91 \\
$04-21-87$ & 46.67 \\
$04-19-88$ & 47.37 \\
$06-01-89$ & 46.42 \\
$04-25-90$ & 43.76 \\
\hline
\end{tabular}

Well UJ-62-58-616

Owner: Chevron Chemical Co., well 2

Depth: 718 feet

Altitude: 7 feet

\begin{tabular}{cc}
\hline Date & Water level \\
\hline $04-11-85$ & 48.42 \\
$05-06-86$ & 45.78 \\
\hline
\end{tabular}

Well UJ-62-58-618

Owner: E.I. DuPont Co., well 103-6

Screen: 637-682 feet

Altitude: 5 feet

\begin{tabular}{cc}
\hline Date & Water level \\
\hline $04-12-85$ & 43.48 \\
$05-06-86$ & 41.78 \\
$05-12-87$ & 42.35 \\
$04-24-90$ & 41.85 \\
\hline
\end{tabular}

Well UJ-62-58-629

Owner: Firestone Petrochemical Center, well P-821

Screen: 595-680 feet

Altitude: 5 feet

\begin{tabular}{cc}
\hline Date & Water level \\
\hline $04-26-90$ & 44.61 \\
\hline
\end{tabular}

Well UJ-62-58-631

Owner: Firestone Petrochemical Center, well P-826

Screen: 585-680 feet

Altitude: 6 feet

\begin{tabular}{cc}
\hline Date & Water level \\
\hline $04-10-85$ & 53.16 \\
\hline
\end{tabular}

Well UJ-62-58-632

Owner: Polysar Gulf Coast, Inc., well 1

Screen: $640-710$ feet

Altitude: 8 feet

\begin{tabular}{cc}
\hline Date & Water level \\
\hline 04-24-90 & 38.34 \\
\hline
\end{tabular}

Well UJ-62-58-633

Owner: Polysar Gulf Coast, Inc., well 2

Screen: 625-725 feet

Altitude: 5 feet

\begin{tabular}{cc}
\hline Date & Water level \\
\hline $04-10-85$ & 38.39 \\
$05-05-86$ & 36.14 \\
$04-24-87$ & 37.60 \\
$04-13-88$ & 35.91 \\
$06-05-89$ & 35.38 \\
$04-25-90$ & 37.18 \\
\hline
\end{tabular}


Table 6. Water levels in observation wells in Orange County and adjacent counties, Texas, 1985-90—Continued

\section{Well UJ-62-58-634}

Owner: Polysar Gulf Coast, Inc., well 3

Screen: 615-715 feet

Altitude: 5 feet

\begin{tabular}{cc}
\hline Date & Water level \\
\hline $04-10-85$ & 43.93 \\
$05-05-86$ & 41.41 \\
$04-24-87$ & 42.63 \\
$04-13-88$ & 43.95 \\
$06-05-89$ & 43.55 \\
$04-25-90$ & 42.59 \\
\hline
\end{tabular}

\section{Well UJ-62-58-638}

Owner: Chevron Chemical Co., well 6

Screen: 634-735 feet

Altitude: 5 feet

\begin{tabular}{cc}
\hline Date & Water level \\
\hline $04-25-90$ & 48.35 \\
\hline
\end{tabular}

\section{Well UJ-62-58-639}

Owner: Polysar Gulf Coast, Inc., well 4

Screen: 620-725 feet

Altitude: 5 feet

\begin{tabular}{cc}
\hline Date & Water level \\
\hline $04-10-85$ & 41.11 \\
$05-05-86$ & 38.80 \\
$04-24-87$ & 42.35 \\
$04-13-88$ & 38.66 \\
$06-05-89$ & 40.17 \\
$04-25-90$ & 41.70 \\
\hline
\end{tabular}

\section{Well UJ-62-58-640}

Owner: Polysar Gulf Coast, Inc., well 5

Screen: 612-718 feet

Altitude: 5 feet

\begin{tabular}{cc}
\hline Date & Water level \\
\hline $04-25-90$ & 43.60 \\
\hline
\end{tabular}

\section{Well UJ-62-58-641}

Owner: E.I. DuPont Co., well 103-6

Screen: 697-702 feet

Altitude: 5 feet

\begin{tabular}{cc}
\hline Date & Water level \\
\hline $04-12-85$ & 44.19 \\
$05-06-86$ & 42.33 \\
$05-12-87$ & 42.23 \\
$04-19-88$ & 42.24 \\
$06-01-89$ & 42.10 \\
$04-24-90$ & 42.36 \\
\hline
\end{tabular}

Well UJ-62-58-702

Owner: Orange County WCID 3 , well 2

Screen: 600-672 feet

Altitude: 10 feet

\begin{tabular}{cc}
\hline Date & Water level \\
\hline $04-10-85$ & 44.20 \\
$04-25-90$ & 41.60 \\
\hline
\end{tabular}

Well UJ-62-58-708

Owner: Gulf States Util. Co., Sabine, well 6

Depth: 465 feet

Altitude: 10 feet

\begin{tabular}{cc}
\hline Date & Water level \\
\hline $04-16-85$ & 111.74 \\
$04-20-90$ & 92.41 \\
\hline
\end{tabular}

Well UJ-62-58-709

Owner: Orange County WCID 3, well 4

Screen: 617-698 feet

Altitude: 10 feet

\begin{tabular}{cc}
\hline Date & Water level \\
\hline $04-10-85$ & 45.75 \\
$04-30-86$ & 42.52 \\
$04-21-87$ & 42.70 \\
$04-13-88$ & 41.32 \\
$05-26-89$ & 41.19 \\
$04-25-90$ & 40.80 \\
\hline
\end{tabular}

Well UJ-62-58-809

Owner: Orange County WCID 3 , well 3

Screen: $570-650$ feet

Altitude: 7 feet

\begin{tabular}{cc}
\hline Date & Water level \\
\hline $04-25-90$ & 40.80 \\
\hline
\end{tabular}

Well UJ-62-58-810

Owner: P.J. Silkwood

Screen: 160-170 feet

Altitude: 5 feet

\begin{tabular}{cc}
\hline Date & Water level \\
\hline $04-10-85$ & 8.99 \\
$04-30-86$ & 10.01 \\
$04-21-87$ & 9.24 \\
$05-26-89$ & 8.52 \\
$04-26-90$ & 8.96 \\
\hline
\end{tabular}

\section{Well UJ-62-59-101}

Owner: City of Orange, well 7

Screen: 555-666 feet

Altitude: 10 feet

\begin{tabular}{cc}
\hline Date & Water level \\
\hline $05-01-86$ & 46.74 \\
$04-21-87$ & 48.92 \\
$04-23-90$ & 47.05 \\
\hline
\end{tabular}

\section{Well UJ-62-59-103}

Owner: City of Orange, well 2

Screen: $565-685$ feet

Altitude: 9 feet

\begin{tabular}{cc}
\hline Date & Water level \\
\hline $04-10-85$ & 48.65 \\
$04-21-87$ & 48.86 \\
$04-21-88$ & 47.13 \\
$06-05-89$ & 45.72 \\
\hline
\end{tabular}


Table 6. Water levels in observation wells in Orange County and adjacent counties, Texas, 1985-90-Continued

Well UJ-62-59-105

Owner: Levingston Shipyard

Screen: $672-737$ feet

Altitude: 9 feet

\begin{tabular}{cc}
\hline Date & Water level \\
\hline $02-20-85$ & 45.80 \\
$04-08-85$ & 45.76 \\
$11-04-85$ & 45.18 \\
$02-27-86$ & 44.32 \\
$04-29-86$ & 44.13 \\
$08-20-86$ & 46.04 \\
$03-25-87$ & 44.02 \\
$08-05-87$ & 45.20 \\
\hline
\end{tabular}

Well UJ-62-59-123

Owner: City of Orange, well 9

Screen: 529-643 feet

Altitude: 10 feet

\begin{tabular}{cc}
\hline Date & Water level \\
\hline $04-10-85$ & 43.86 \\
$05-01-86$ & 36.84 \\
$04-21-87$ & 43.74 \\
$04-21-88$ & 42.18 \\
$06-05-89$ & 41.28 \\
$04-23-90$ & 42.56
\end{tabular}

\section{Hardin County}

Well LH-61-47-208

Owner: City of Silsbee, well 3

Screen: 442-842 feet

Altitude: 80 feet

\begin{tabular}{cc}
\hline Date & Water level \\
\hline $04-11-85$ & 101.73 \\
$05-07-86$ & 104.92 \\
$04-23-87$ & 96.57 \\
$05-25-89$ & 92.02 \\
$04-30-90$ & 97.49
\end{tabular}

Well LH-61-47-210

Owner: City of Silsbee, well 2a

Screen: 782-890 feet

Altitude: 80 feet

\begin{tabular}{cc}
\hline Date & Water level \\
\hline $04-11-85$ & 112.31 \\
$05-07-86$ & 116.75 \\
$04-23-87$ & 111.17 \\
$04-20-88$ & 112.85 \\
$05-25-89$ & 111.94 \\
$04-30-90$ & 112.29 \\
\hline
\end{tabular}

\section{Well LH-61-47-304}

Owner: City of Silsbee, well 4

Screen: 595-905 feet

Altitude: 80 feet

\begin{tabular}{cc}
\hline Date & Water level \\
\hline 04-30-90 & 103.46 \\
\hline
\end{tabular}

\section{Well LH-61-47-804}

Owner: Lumberton MUD, well 2

Screen: $395-458$ feet

Altitude: 55 feet

\begin{tabular}{cc}
\hline Date & Water level \\
\hline $04-10-85$ & 61.80 \\
$05-07-86$ & 58.47 \\
$04-23-87$ & 56.86 \\
$04-20-88$ & 60.70 \\
$05-26-89$ & 59.39 \\
$04-27-90$ & 47.83 \\
\hline
\end{tabular}

Well LH-61-55-104

Owner: City of Beaumont, Loeb, well 3

Screen: $290-765$ feet

Altitude: 40 feet

\begin{tabular}{cc}
\hline Date & Water level \\
\hline $05-06-86$ & ${ }^{1} 63.5$ \\
$03-10-87$ & ${ }^{1} 58.5$ \\
$03-01-88$ & ${ }^{1} 58.5$ \\
$03-16-89$ & ${ }^{1} 61.5$ \\
$04-27-90$ & 67.60 \\
\hline
\end{tabular}

${ }^{1}$ Reported by well owner.

\section{Well LH-61-55-105}

Owner: Lumberton MUD, well 3

Screen: 343-770 feet

Altitude: 43 feet

\begin{tabular}{cc}
\hline Date & Water level \\
\hline $04-10-85$ & 172.1 \\
$05-07-86$ & 80.53 \\
$04-23-87$ & 61.82 \\
$04-20-88$ & 74.73 \\
$05-26-89$ & 70.50 \\
$04-27-90$ & 77.50 \\
\hline
\end{tabular}

${ }^{1}$ Reported by well owner.
Well LH-61-55-203

Owner: City of Beaumont, Loeb, well 2

Screen: $301-775$ feet

Altitude: 26 feet

\begin{tabular}{cc}
\hline Date & Water level \\
\hline $04-17-86$ & ${ }^{1} 75.5$ \\
$04-28-87$ & ${ }^{1} 55.5$ \\
$03-01-88$ & 182.5 \\
$03-16-89$ & 162.5 \\
$04-27-90$ & 94.40 \\
\hline
\end{tabular}

${ }^{1}$ Reported by well owner.

\section{Well LH-61-55-204}

Owner: City of Beaumont, Loeb, well 1

Screen: $311-780$ feet

Altitude: 25 feet

\begin{tabular}{cc}
\hline Date & Water level \\
\hline $05-06-86$ & 171.0 \\
$03-10-87$ & 157.5 \\
$03-01-88$ & 158.5 \\
$02-09-89$ & 177.5 \\
$04-27-90$ & 57.19 \\
\hline
\end{tabular}

${ }^{1}$ Reported by well owner.

Well LH-61-55-206

Owner: Lumberton MUD, well 1

Screen: $380-443$ feet

Altitude: 35 feet

\begin{tabular}{cc}
\hline Date & Water level \\
\hline $04-10-85$ & 73.10 \\
$04-27-90$ & 66.40
\end{tabular}

\section{Jasper County}

\section{Well PR-61-48-209}

Owner: Temple-Inland Forest Products Corp.

Screen: 213-594 feet

Altitude: 45 feet

\begin{tabular}{cc}
\hline Date & Water level \\
\hline $12-10-85$ & 39.18 \\
$12-02-86$ & 36.26 \\
$04-23-87$ & 33.15 \\
$11-10-87$ & 32.28 \\
$04-30-90$ & 37.13 \\
\hline
\end{tabular}


Table 6. Water levels in observation wells in Orange County and adjacent counties, Texas, 1985-90-Continued

\section{Well PR-61-48-214}

Owner: Southern Pine Co.

Depth: 226 feet

Altitude: 42 feet

\begin{tabular}{cc}
\hline Date & Water level \\
\hline $04-11-85$ & 35.65 \\
$05-07-86$ & 37.06 \\
$04-23-87$ & 35.91 \\
$04-20-88$ & 37.32 \\
$05-26-89$ & 36.63 \\
\hline
\end{tabular}

\section{Well PR-61-48-221}

Owner: Temple-Inland Forest Products Corp.

Screen: 723-1,264 feet

Altitude: 45 feet

\begin{tabular}{cc}
\hline Date & Water level \\
\hline $12-10-85$ & 200.07 \\
$12-02-86$ & 199.47 \\
$04-23-87$ & 197.44 \\
$04-30-90$ & 200.22 \\
\hline
\end{tabular}

\section{Well PR-61-48-701}

Owner: Larkin Franklin

Screen: $1,210-1,250$ feet

Altitude: 35 feet

\begin{tabular}{cc}
\hline Date & Water level \\
\hline $05-01-90$ & 74.50 \\
\hline
\end{tabular}

\section{Well PR-61-48-702}

Owner: J.C. Chance

Screen: 448-468 feet

Altitude: 30 feet

\begin{tabular}{cc}
\hline Date & Water level \\
\hline $04-15-85$ & 45.97 \\
$04-28-86$ & 46.13 \\
$05-11-87$ & 42.87 \\
$04-11-88$ & 42.48 \\
$05-26-89$ & 42.02 \\
$05-01-90$ & 44.79 \\
\hline
\end{tabular}

\section{Well PR-62-17-902}

Owner: W.S. Gillespie

Screen: $300-325$ feet

Altitude: 119 feet

\begin{tabular}{cc}
\hline Date & Water level \\
\hline $12-10-85$ & 33.31 \\
$12-02-86$ & 30.30 \\
$11-11-87$ & 31.13 \\
$05-25-89$ & 30.85 \\
$05-01-90$ & 28.51 \\
\hline
\end{tabular}

\section{Well PR-62-25-308}

Owner: S. Kirbyville Rural Water Supply Corp.

Screen: 575-625 feet

Altitude: 101 feet

\begin{tabular}{cc}
\hline Date & Water level \\
\hline $05-02-90$ & 65.79 \\
\hline
\end{tabular}

Well PR-62-33-211

Owner: Cougar Country Subdivision

Screen: 495-535 feet

Altitude: 85 feet

\begin{tabular}{cc}
\hline Date & Water level \\
\hline $04-12-85$ & 72.38 \\
$04-23-87$ & 76.40 \\
\hline
\end{tabular}

\section{Well PR-62-33-401}

Owner: City of Buna WCID 1, well 2

Screen: $230-275$ feet

Altitude: 72 feet

\begin{tabular}{cc}
\hline Date & Water level \\
\hline $04-12-85$ & 30.91 \\
$04-23-87$ & 29.50 \\
$04-20-88$ & 29.70 \\
$05-25-89$ & 31.85 \\
$05-02-90$ & 29.97 \\
\hline
\end{tabular}

Well PR-62-33-409

Owner: City of Buna WCID 1, well 1

Screen: 513-777 feet

Altitude: 72 feet

\begin{tabular}{cc}
\hline Date & Water level \\
\hline $04-12-85$ & 89.86 \\
$05-07-86$ & 91.83 \\
$05-25-89$ & 82.33 \\
$05-02-90$ & 87.53 \\
\hline
\end{tabular}

\section{Jefferson County}

Well PT-61-64-502

Owner: Gulf States Util. Co., Neches, well 3

Screen: $306-435$ feet

Altitude: 10 feet

\begin{tabular}{cc}
\hline Date & Water level \\
\hline $04-12-85$ & 32.98 \\
$05-06-86$ & 32.13 \\
$04-24-87$ & 31.96 \\
$04-13-88$ & 31.05 \\
$05-26-89$ & 30.91 \\
$04-26-90$ & 29.69 \\
\hline
\end{tabular}

Well PT-61-64-509

Owner: Gulf States Util. Co., Neches, well 2

Screen: $380-542$ feet

Altitude: 8 feet

\begin{tabular}{cc}
\hline Date & Water level \\
\hline $04-12-85$ & 32.79 \\
\hline
\end{tabular}

Well PT-63-01-606

Owner: City of Groves

Depth: 814 feet

Altitude: 5 feet

\begin{tabular}{cc}
\hline Date & Water level \\
\hline $04-11-85$ & 32.76 \\
$05-06-86$ & 33.14 \\
$04-24-87$ & 31.29 \\
$04-13-88$ & 30.77 \\
$05-26-89$ & 30.16 \\
$04-27-90$ & 29.42 \\
\hline
\end{tabular}


Table 6. Water levels in observation wells in Orange County and adjacent counties, Texas, 1985-90—Continued

\section{Newton County}

Well TZ-62-18-801

Owner: Texas Forest Service

Screen: $186-210$ feet

Altitude: 115 feet

\begin{tabular}{cc}
\hline Date & Water level \\
\hline $04-11-85$ & 40.72 \\
$05-07-86$ & 42.63 \\
$04-23-87$ & 41.68 \\
$04-20-88$ & 41.74 \\
$05-26-89$ & 41.46 \\
$05-01-90$ & 40.23 \\
\hline
\end{tabular}

Well TZ-62-42-102

Owner: Frenchies Longron

Screen: $179-429$ feet

Altitude: 37 feet

\begin{tabular}{cc}
\hline Date & Water level \\
\hline $04-08-85$ & 30.94 \\
$05-07-86$ & 30.41 \\
$04-22-87$ & 30.10 \\
\hline
\end{tabular}

Well TZ-62-42-603

Owner: L.S. Arrendell

Screen: $184-190$ feet

Altitude: 22 feet

\begin{tabular}{cc}
\hline Date & Water level \\
\hline $04-08-85$ & 5.96 \\
$04-29-86$ & 7.81 \\
\hline
\end{tabular}

\section{Well TZ-62-42-904}

Owner: L.A. Whidden

Depth: 270 feet

Altitude: 34 feet

\begin{tabular}{cc}
\hline Date & Water level \\
\hline $04-08-85$ & 35.81 \\
$04-29-86$ & 36.18 \\
$04-22-87$ & 34.92 \\
$04-18-88$ & 34.52 \\
$05-25-89$ & 34.77 \\
$05-02-90$ & 34.22 \\
\hline
\end{tabular}

Table 7. Records of selected wells in Orange County, Texas, 1985-90

Water-bearing unit : CHCTL, lower unit of Chicot aquifer; CHCTU, upper unit of Chicot aquifer

Water level

: Reported water levels in feet

Use of water

: $\mathrm{P}$, public supply; $\mathrm{N}$, industrial; $\mathrm{C}$, commercial; $\mathrm{D}$, domestic

Type of data available : W, water-level measurements (table 6); Q, chemical analyses (table 8) [ft, feet; in., inches; CSD, Consolidated School District; --, data not available]

\begin{tabular}{|c|c|c|c|c|c|c|c|}
\hline \multirow[b]{2}{*}{$\begin{array}{c}\text { Well } \\
\text { number }\end{array}$} & \multirow[b]{2}{*}{ Owner } & \multirow[b]{2}{*}{ Driller } & \multirow[b]{2}{*}{$\begin{array}{l}\text { Date } \\
\text { com- } \\
\text { pleted }\end{array}$} & \multirow[b]{2}{*}{$\begin{array}{c}\text { Well } \\
\text { depth } \\
\text { (feet) }\end{array}$} & \multirow[b]{2}{*}{$\begin{array}{c}\text { Well } \\
\text { diameter } \\
\text { (inches) }\end{array}$} & \multicolumn{2}{|c|}{ Well screen } \\
\hline & & & & & & $\begin{array}{c}\text { Total } \\
\text { length } \\
\text { (ft) }\end{array}$ & $\begin{array}{l}\text { Depth } \\
\text { interval } \\
\text { (ft) }\end{array}$ \\
\hline UJ-61-64-314 & David Wilkinson & $\begin{array}{c}\text { Jones Water Well } \\
\text { Drilling Co. }\end{array}$ & 1985 & 562 & 2 & 10 & $552-562$ \\
\hline UJ-62-50-107 & $\begin{array}{l}\text { Mauriceville Water Supply } \\
\text { Corp. }\end{array}$ & $\begin{array}{l}\text { Baison Water Well } \\
\text { Drilling Co. }\end{array}$ & 1990 & 730 & $\begin{array}{c}10.75 \\
6.62\end{array}$ & 50 & $680-730$ \\
\hline UJ-62-50-912 & $\begin{array}{l}\text { Little Cypress-Mauriceville } \\
\text { C.S.D. }\end{array}$ & $\begin{array}{l}\text { Pascal Water Well } \\
\text { Drilling Co. }\end{array}$ & 1987 & 510 & 6 & 50 & $460-510$ \\
\hline UJ-62-58-208 & J.M. Huber Plastics & $\begin{array}{l}\text { Baison Water Well } \\
\text { Drilling Co. }\end{array}$ & 1989 & 557 & 8,4 & 30 & $509-539$ \\
\hline UJ-62-58-514 & Doan's Nursery & $\begin{array}{l}\text { Paskell Water Well } \\
\text { Drilling Co. }\end{array}$ & 1975 & 400 & 4 & -- & -- \\
\hline UJ-62-58-515 & Doan's Nursery & $\begin{array}{l}\text { Paskell Water Well } \\
\text { Drilling Co. }\end{array}$ & 1983 & 275 & 4 & -- & -- \\
\hline \multirow{2}{*}{$\begin{array}{c}\text { Well } \\
\text { number }\end{array}$} & \multirow{2}{*}{$\begin{array}{l}\text { Water-bearing } \\
\text { unit }\end{array}$} & land surface & \multicolumn{3}{|c|}{ Water level } & \multirow{2}{*}{$\begin{array}{l}\text { Use of } \\
\text { water }\end{array}$} & \multirow{2}{*}{$\begin{array}{c}\text { Type of data } \\
\text { available }\end{array}$} \\
\hline & & $\begin{array}{l}\text { ove sea level } \\
\text { (ft) }\end{array}$ & $\begin{array}{c}\text { Below land } s \\
\text { (ft) }\end{array}$ & & $\begin{array}{c}\text { Date of } \\
\text { measurement }\end{array}$ & & \\
\hline UJ-61-64-314 & CHCTL & 16 & -- & & -- & $\mathrm{D}$ & $\mathrm{Q}$ \\
\hline UJ-62-50-107 & CHCTL & 26 & 38 & & $04 / 28 / 90$ & $\mathrm{P}$ & $\mathrm{W}$ \\
\hline UJ-62-50-912 & CHCTL & 16 & 48.0 & & $05 / 12 / 87$ & $\mathrm{P}$ & $\mathrm{Q}, \mathrm{W}$ \\
\hline UJ-62-58-208 & CHCTL & 14 & 50 & & 07/01/89 & $\mathrm{N}$ & $\mathrm{W}$ \\
\hline UJ-62-58-514 & CHCTL & 8 & -- & & -- & $\mathrm{C}$ & $\mathrm{Q}, \mathrm{W}$ \\
\hline UJ-62-58-515 & CHCTU & 8 & -- & & -- & $\mathrm{C}$ & $\mathrm{Q}, \mathrm{W}$ \\
\hline
\end{tabular}


Table 8. Chemical analyses of water from selected wells in Orange County, Texas, 1985-90

Owner : WCID, Water Control and Improvement District; ISD, Independent School District; CSD, Consolidated School District; Util., Utilities

Water-bearing unit : CHCTL, lower unit of Chicot aquifer; CHCTU, upper unit of Chicot aquifer

[ft, feet; $\mu \mathrm{S} / \mathrm{cm}$, microsiemens per centimeter at 25 degrees Celsius; ${ }^{\circ} \mathrm{C}$, degrees Celsius; $\mathrm{mg} / \mathrm{L}$, milligrams per liter; --, not measured-water sampled from storage tank]

\begin{tabular}{|c|c|c|c|c|c|c|c|c|}
\hline Well number & Owner & $\begin{array}{l}\text { Screened } \\
\text { interval } \\
\text { or depth } \\
\text { (ft) }\end{array}$ & $\begin{array}{c}\text { Water- } \\
\text { bearing } \\
\text { unit }\end{array}$ & $\begin{array}{l}\text { Date of } \\
\text { sample }\end{array}$ & $\begin{array}{c}\text { Specific } \\
\text { conduc- } \\
\text { tance } \\
(\mu \mathrm{S} / \mathrm{cm})\end{array}$ & $\begin{array}{c}\text { pH } \\
\text { (standard } \\
\text { units) }\end{array}$ & $\begin{array}{c}\text { Temper- } \\
\text { ature } \\
\left({ }^{\circ} \mathrm{C}\right)\end{array}$ & $\begin{array}{c}\text { Chloride, } \\
\text { dissolved } \\
\text { (mg/L) }\end{array}$ \\
\hline UJ-61-56-614 & $\begin{array}{l}\text { Pine Forest School } \\
\text { District }\end{array}$ & $453-483$ & CHCTL & $\begin{array}{l}11-05-85 \\
10-28-86 \\
10-26-87 \\
10-18-88 \\
11-21-89\end{array}$ & $\begin{array}{l}622 \\
718 \\
646 \\
709 \\
670\end{array}$ & $\begin{array}{c}-- \\
-- \\
-- \\
-- \\
7.9\end{array}$ & $\begin{array}{l}-- \\
-- \\
-- \\
-- \\
22.0\end{array}$ & $\begin{array}{l}56 \\
90 \\
66 \\
80 \\
68\end{array}$ \\
\hline UJ-61-56-911 & $\begin{array}{l}\text { Community Water } \\
\text { System }\end{array}$ & $468-486$ & CHCTL & $\begin{array}{l}11-05-85 \\
10-28-86 \\
10-26-87 \\
10-18-88 \\
12-01-89\end{array}$ & $\begin{array}{l}717 \\
743 \\
734 \\
791 \\
841\end{array}$ & $\begin{array}{l}-- \\
-- \\
-- \\
-- \\
8.1\end{array}$ & $\begin{array}{l}-- \\
-- \\
-- \\
-- \\
21.0\end{array}$ & $\begin{array}{l}100 \\
100 \\
100 \\
120 \\
130\end{array}$ \\
\hline UJ-61-56-919 & $\begin{array}{l}\text { Orange County WCID 1, } \\
\text { well } 3\end{array}$ & $385-420$ & CHCTL & $\begin{array}{l}11-12-85 \\
11-03-86 \\
10-30-87 \\
10-21-88 \\
11-21-89\end{array}$ & $\begin{array}{l}490 \\
476 \\
506 \\
495 \\
493\end{array}$ & $\begin{array}{l}7.8 \\
7.6 \\
7.5 \\
7.4 \\
7.5\end{array}$ & $\begin{array}{l}22.5 \\
22.5 \\
24.0 \\
23.0 \\
21.5\end{array}$ & $\begin{array}{l}58 \\
48 \\
48 \\
49 \\
51\end{array}$ \\
\hline UJ-61-56-922 & $\begin{array}{l}\text { Orange County WCID 1, } \\
\text { well } 4\end{array}$ & $284-490$ & CHCTL & $\begin{array}{l}11-12-85 \\
11-03-86 \\
10-30-87 \\
10-21-88 \\
11-21-89\end{array}$ & $\begin{array}{l}477 \\
471 \\
501 \\
487 \\
488\end{array}$ & $\begin{array}{l}7.9 \\
7.9 \\
7.8 \\
7.6 \\
8.1\end{array}$ & $\begin{array}{l}22.5 \\
22.0 \\
22.0 \\
22.0 \\
21.5\end{array}$ & $\begin{array}{l}50 \\
44 \\
44 \\
47 \\
46\end{array}$ \\
\hline UJ-61-56-923 & $\begin{array}{l}\text { Orange County WCID 1, } \\
\text { Tiger Lake }\end{array}$ & $430-460$ & CHCTL & $\begin{array}{l}10-21-88 \\
04-18-90\end{array}$ & $\begin{array}{l}475 \\
471\end{array}$ & $\begin{array}{l}7.7 \\
7.6\end{array}$ & $\begin{array}{l}22.0 \\
21.5\end{array}$ & $\begin{array}{l}34 \\
34\end{array}$ \\
\hline UJ-61-64-302 & Vidor ISD & 521 & CHCTL & $\begin{array}{l}11-08-85 \\
11-05-86 \\
10-18-88 \\
11-21-89\end{array}$ & $\begin{array}{l}1,910 \\
1,960 \\
1,980 \\
1,920\end{array}$ & $\begin{array}{c}-- \\
-- \\
-- \\
7.9\end{array}$ & $\begin{array}{l}-- \\
-- \\
-- \\
23.5\end{array}$ & $\begin{array}{l}500 \\
490 \\
480 \\
490\end{array}$ \\
\hline UJ-61-64-306 & Larry Brewer & $525-545$ & CHCTL & $\begin{array}{l}11-05-85 \\
10-28-86 \\
10-26-87 \\
10-18-88 \\
12-01-89\end{array}$ & $\begin{array}{l}1,320 \\
1,580 \\
1,340 \\
1,330 \\
1,380\end{array}$ & $\begin{array}{l}-- \\
-- \\
-- \\
-- \\
8.3\end{array}$ & $\begin{array}{l}-- \\
-- \\
-- \\
-- \\
22.5\end{array}$ & $\begin{array}{l}300 \\
370 \\
290 \\
300 \\
300\end{array}$ \\
\hline UJ-61-64-314 & David Wilkinson & $552-562$ & CHCTL & $\begin{array}{l}11-05-85 \\
10-28-86 \\
10-28-87 \\
10-17-88 \\
11-22-89\end{array}$ & $\begin{array}{l}1,630 \\
1,690 \\
1,660 \\
1,630 \\
1,650\end{array}$ & $\begin{array}{l}-- \\
-- \\
-- \\
-- \\
8.0\end{array}$ & $\begin{array}{l}-- \\
-- \\
-- \\
-- \\
23.0\end{array}$ & $\begin{array}{l}400 \\
400 \\
390 \\
390 \\
380\end{array}$ \\
\hline UJ-62-49-302 & $\begin{array}{l}\text { Mauriceville Water } \\
\text { Supply Corp., well } 1\end{array}$ & $320-350$ & CHCTL & $\begin{array}{l}11-15-85 \\
11-29-89\end{array}$ & $\begin{array}{l}180 \\
225\end{array}$ & $\begin{array}{l}6.9 \\
6.8\end{array}$ & $\begin{array}{l}22.5 \\
21.0\end{array}$ & $\begin{array}{l}16 \\
20\end{array}$ \\
\hline UJ-62-49-703 & James Smith & $693-703$ & CHCTL & $\begin{array}{l}11-12-85 \\
10-29-86 \\
11-03-87 \\
11-28-89\end{array}$ & $\begin{array}{l}2,340 \\
2,330 \\
2,420 \\
1,510\end{array}$ & $\begin{array}{c}7.9 \\
-- \\
-- \\
8.1\end{array}$ & $\begin{array}{l}23.5 \\
-- \\
-- \\
20.0\end{array}$ & $\begin{array}{l}640 \\
640 \\
640 \\
360\end{array}$ \\
\hline
\end{tabular}


Table 8. Chemical analyses of water from selected wells in Orange County, Texas, 1985-90-Continued

\begin{tabular}{|c|c|c|c|c|c|c|c|c|}
\hline Well number & Owner & $\begin{array}{c}\text { Screened } \\
\text { interval } \\
\text { or depth } \\
\text { (ft) }\end{array}$ & $\begin{array}{c}\text { Water- } \\
\text { bearing } \\
\text { unit }\end{array}$ & $\begin{array}{l}\text { Date of } \\
\text { sample }\end{array}$ & $\begin{array}{c}\text { Specific } \\
\text { conduc- } \\
\text { tance } \\
(\mu \mathrm{S} / \mathrm{cm})\end{array}$ & $\begin{array}{c}\mathrm{pH} \\
\text { (standard } \\
\text { units) }\end{array}$ & $\begin{array}{c}\text { Temper- } \\
\text { ature } \\
\left({ }^{\circ} \mathbf{C}\right)\end{array}$ & $\begin{array}{c}\text { Chloride, } \\
\text { dissolved } \\
\text { (mg/L) }\end{array}$ \\
\hline UJ-62-49-804 & Parkview Subdivision & $470-490$ & CHCTL & $11-08-85$ & 215 & -- & -- & 20 \\
\hline UJ-62-49-904 & $\begin{array}{l}\text { Texas Department of } \\
\text { Transportation }\end{array}$ & $399-415$ & CHCTL & $\begin{array}{l}11-04-85 \\
10-30-86 \\
10-28-87 \\
10-18-88 \\
11-29-89\end{array}$ & $\begin{array}{l}238 \\
242 \\
234 \\
251 \\
229\end{array}$ & $\begin{array}{l}-- \\
-- \\
-- \\
-- \\
7.5\end{array}$ & $\begin{array}{l}-- \\
-- \\
-- \\
-- \\
22.0\end{array}$ & $\begin{array}{l}16 \\
20 \\
20 \\
18 \\
15\end{array}$ \\
\hline UJ-62-49-905 & $\begin{array}{l}\text { Texas Department of } \\
\text { Transportation }\end{array}$ & $378-394$ & CHCTL & $\begin{array}{l}11-12-85 \\
10-21-88 \\
11-29-89\end{array}$ & $\begin{array}{l}237 \\
244 \\
244\end{array}$ & $\begin{array}{c}7.3 \\
-- \\
7.4\end{array}$ & $\begin{array}{l}23.0 \\
-- \\
22.0\end{array}$ & $\begin{array}{l}14 \\
16 \\
17\end{array}$ \\
\hline UJ-62-50-106 & $\begin{array}{l}\text { Mauriceville Water } \\
\text { Supply Corp., well } 2\end{array}$ & $445-480$ & CHCTL & $\begin{array}{l}11-15-85 \\
11-29-89\end{array}$ & $\begin{array}{l}228 \\
242\end{array}$ & $\begin{array}{l}7.0 \\
6.6\end{array}$ & $\begin{array}{l}23.0 \\
23.0\end{array}$ & $\begin{array}{l}28 \\
29\end{array}$ \\
\hline UJ-62-50-807 & Henry L. Wilson & $442-454$ & CHCTL & $\begin{array}{l}10-24-88 \\
11-29-89\end{array}$ & $\begin{array}{l}268 \\
260\end{array}$ & $\begin{array}{c}-- \\
7.2\end{array}$ & $\begin{array}{l}-- \\
18.0\end{array}$ & $\begin{array}{l}24 \\
23\end{array}$ \\
\hline UJ-62-50-808 & H.D. Womack & $643-655$ & CHCTL & $\begin{array}{l}11-14-85 \\
10-31-86 \\
11-02-87 \\
10-24-88 \\
04-18-90\end{array}$ & $\begin{array}{l}625 \\
658 \\
652 \\
740 \\
770\end{array}$ & $\begin{array}{c}6.8 \\
-- \\
-- \\
-- \\
6.9\end{array}$ & $\begin{array}{l}23.5 \\
-- \\
-- \\
-- \\
21.0\end{array}$ & $\begin{array}{l}130 \\
130 \\
140 \\
150 \\
160\end{array}$ \\
\hline UJ-62-50-910 & $\begin{array}{l}\text { Little Cypress- } \\
\text { Mauriceville CSD }\end{array}$ & $450-500$ & CHCTL & $\begin{array}{l}11-07-85 \\
11-05-86 \\
11-02-87\end{array}$ & $\begin{array}{l}310 \\
326 \\
373\end{array}$ & $\begin{array}{l}-- \\
-- \\
--\end{array}$ & $\begin{array}{l}-- \\
-- \\
--\end{array}$ & $\begin{array}{l}27 \\
30 \\
42\end{array}$ \\
\hline UJ-62-50-911 & City of Orange, well 9 & $454-618$ & CHCTL & $\begin{array}{l}11-14-85 \\
10-31-86 \\
10-27-87 \\
10-25-88 \\
11-30-89\end{array}$ & $\begin{array}{l}514 \\
542 \\
617 \\
657 \\
745\end{array}$ & $\begin{array}{l}7.2 \\
7.3 \\
6.8 \\
7.2 \\
7.3\end{array}$ & $\begin{array}{l}24.5 \\
24.0 \\
24.0 \\
24.0 \\
23.5\end{array}$ & $\begin{array}{r}70 \\
79 \\
98 \\
110 \\
130\end{array}$ \\
\hline UJ-62-50-912 & $\begin{array}{l}\text { Little Cypress- } \\
\text { Mauriceville CSD }\end{array}$ & $460-510$ & CHCTL & $\begin{array}{l}10-27-88 \\
12-05-89\end{array}$ & $\begin{array}{l}314 \\
314\end{array}$ & $\begin{array}{l}7.4 \\
7.0\end{array}$ & $\begin{array}{l}23.0 \\
24.5\end{array}$ & $\begin{array}{l}30 \\
32\end{array}$ \\
\hline UJ-62-51-706 & J.M. Huber Corp. & $428-488$ & CHCTL & $\begin{array}{l}11-15-85 \\
11-05-86 \\
11-02-87 \\
10-27-88 \\
11-28-89\end{array}$ & $\begin{array}{l}349 \\
344 \\
343 \\
340 \\
341\end{array}$ & $\begin{array}{c}7.4 \\
-- \\
-- \\
7.4 \\
7.2\end{array}$ & $\begin{array}{l}23.5 \\
-- \\
-- \\
24.0 \\
22.0\end{array}$ & $\begin{array}{l}24 \\
24 \\
25 \\
23 \\
27\end{array}$ \\
\hline UJ-62-57-203 & Joe M. Heinen & 740 & CHCTL & $\begin{array}{l}11-08-85 \\
10-29-86 \\
10-28-87 \\
10-17-88 \\
12-05-89\end{array}$ & $\begin{array}{l}446 \\
455 \\
442 \\
463 \\
458\end{array}$ & $\begin{array}{l}-- \\
-- \\
-- \\
-- \\
--\end{array}$ & $\begin{array}{l}-- \\
-- \\
-- \\
-- \\
--\end{array}$ & $\begin{array}{l}53 \\
51 \\
51 \\
51 \\
54\end{array}$ \\
\hline UJ-62-57-401 & $\begin{array}{l}\text { Texas Eastern Gas } \\
\text { Pipeline Co. }\end{array}$ & $448-468$ & CHCTL & $\begin{array}{l}11-05-85 \\
11-04-86 \\
10-29-87 \\
10-19-88 \\
12-06-89\end{array}$ & $\begin{array}{l}477 \\
465 \\
485 \\
497 \\
494\end{array}$ & $\begin{array}{l}-- \\
-- \\
-- \\
-- \\
8.4\end{array}$ & $\begin{array}{l}-- \\
-- \\
-- \\
-- \\
21.0\end{array}$ & $\begin{array}{r}62 \\
60 \\
100 \\
67 \\
68\end{array}$ \\
\hline UJ-62-57-403 & $\begin{array}{l}\text { Gulf States Util. Co., } \\
\text { Vidor, well } 1\end{array}$ & $433-483$ & CHCTL & $\begin{array}{l}11-13-85 \\
11-04-86 \\
10-28-87 \\
10-20-88 \\
11-22-89\end{array}$ & $\begin{array}{l}1,510 \\
1,240 \\
1,380 \\
1,430 \\
1,550\end{array}$ & $\begin{array}{l}7.9 \\
7.6 \\
7.5 \\
7.5 \\
7.8\end{array}$ & $\begin{array}{l}24.0 \\
23.5 \\
24.0 \\
23.5 \\
23.5\end{array}$ & $\begin{array}{l}380 \\
300 \\
350 \\
350 \\
380\end{array}$ \\
\hline
\end{tabular}


Table 8. Chemical analyses of water from selected wells in Orange County, Texas, 1985-90-Continued

\begin{tabular}{|c|c|c|c|c|c|c|c|c|}
\hline Well number & Owner & $\begin{array}{c}\text { Screened } \\
\text { interval } \\
\text { or depth } \\
\text { (ft) }\end{array}$ & $\begin{array}{c}\text { Water- } \\
\text { bearing } \\
\text { unit }\end{array}$ & $\begin{array}{l}\text { Date of } \\
\text { sample }\end{array}$ & $\begin{array}{c}\text { Specific } \\
\text { conduc- } \\
\text { tance } \\
(\mu \mathrm{S} / \mathrm{cm})\end{array}$ & $\begin{array}{c}\text { pH } \\
\text { (standard } \\
\text { units) }\end{array}$ & $\begin{array}{c}\text { Temper- } \\
\text { ature } \\
\left({ }^{\circ} \mathrm{C}\right)\end{array}$ & $\begin{array}{c}\text { Chloride, } \\
\text { dissolved } \\
\text { (mg/L) }\end{array}$ \\
\hline UJ-62-57-404 & $\begin{array}{l}\text { Gulf States Util. Co., } \\
\text { Vidor, well } 2\end{array}$ & $430-481$ & CHCTL & $\begin{array}{l}11-13-85 \\
11-04-86\end{array}$ & $\begin{array}{l}3,580 \\
1,880\end{array}$ & $\begin{array}{l}7.5 \\
7.7\end{array}$ & $\begin{array}{l}24.5 \\
23.5\end{array}$ & $\begin{array}{r}1,100 \\
510\end{array}$ \\
\hline UJ-62-57-406 & $\begin{array}{l}\text { Gulf States Util. Co., } \\
\text { Vidor, well } 6\end{array}$ & $430-480$ & CHCTL & $\begin{array}{l}10-28-87 \\
10-20-88\end{array}$ & $\begin{array}{l}1,380 \\
1,430\end{array}$ & $\begin{array}{l}7.5 \\
7.6\end{array}$ & $\begin{array}{l}24.0 \\
24.0\end{array}$ & $\begin{array}{l}350 \\
360\end{array}$ \\
\hline UJ-62-57-407 & $\begin{array}{l}\text { Gulf States Util. Co., } \\
\text { Vidor, well } 4\end{array}$ & $320-370$ & CHCTL & $11-13-85$ & 1,510 & 7.7 & 24.0 & 380 \\
\hline UJ-62-57-408 & $\begin{array}{l}\text { Gulf States Util. Co., } \\
\text { Vidor, well } 5\end{array}$ & $343-383$ & CHCTL & $\begin{array}{l}11-13-85 \\
11-04-86 \\
10-28-87 \\
10-20-88\end{array}$ & $\begin{array}{l}1,520 \\
1,890 \\
1,440 \\
1,420\end{array}$ & $\begin{array}{l}7.8 \\
7.7 \\
7.6 \\
8.0\end{array}$ & $\begin{array}{l}24.5 \\
24.0 \\
24.0 \\
24.0\end{array}$ & $\begin{array}{l}380 \\
490 \\
350 \\
360\end{array}$ \\
\hline UJ-62-57-501 & $\begin{array}{l}\text { Enron Gas Pipeline } \\
\text { Operating Co. }\end{array}$ & $405-435$ & CHCTL & $\begin{array}{l}11-08-85 \\
10-29-86 \\
10-29-87 \\
10-17-88 \\
12-06-89\end{array}$ & $\begin{array}{l}345 \\
374 \\
369 \\
377 \\
360\end{array}$ & $\begin{array}{l}-- \\
-- \\
-- \\
-- \\
--\end{array}$ & $\begin{array}{l}-- \\
-- \\
-- \\
-- \\
--\end{array}$ & $\begin{array}{l}31 \\
35 \\
32 \\
29 \\
28\end{array}$ \\
\hline UJ-62-57-502 & Texaco Inc. & $478-528$ & CHCTL & $\begin{array}{l}11-08-85 \\
11-05-86 \\
11-03-87 \\
10-20-88 \\
12-06-89\end{array}$ & $\begin{array}{l}342 \\
345 \\
355 \\
361 \\
352\end{array}$ & $\begin{array}{l}-- \\
-- \\
-- \\
-- \\
8.1\end{array}$ & $\begin{array}{l}-- \\
-- \\
-- \\
-- \\
19.0\end{array}$ & $\begin{array}{l}22 \\
23 \\
22 \\
22 \\
22\end{array}$ \\
\hline UJ-62-57-605 & Wade Granger & $469-489$ & CHCTL & $\begin{array}{l}11-05-85 \\
10-29-86 \\
10-27-87 \\
10-25-88 \\
12-05-89\end{array}$ & $\begin{array}{l}312 \\
325 \\
309 \\
322 \\
310\end{array}$ & $\begin{array}{l}-- \\
-- \\
-- \\
-- \\
7.8\end{array}$ & $\begin{array}{l}-- \\
-- \\
-- \\
-- \\
23.0\end{array}$ & $\begin{array}{l}28 \\
27 \\
28 \\
29 \\
29\end{array}$ \\
\hline UJ-62-57-904 & $\begin{array}{l}\text { Gulf States Util. Co., } \\
\text { Sabine, well } 4\end{array}$ & $432-455$ & CHCTL & $\begin{array}{l}11-06-86 \\
11-04-87 \\
12-06-89\end{array}$ & $\begin{array}{l}470 \\
492 \\
486\end{array}$ & $\begin{array}{l}8.1 \\
7.9 \\
7.9\end{array}$ & $\begin{array}{l}23.5 \\
24.0 \\
23.0\end{array}$ & $\begin{array}{l}40 \\
44 \\
47\end{array}$ \\
\hline UJ-62-57-905 & $\begin{array}{l}\text { Gulf States Util. Co., } \\
\text { Sabine, well } 5\end{array}$ & $422-461$ & CHCTL & $\begin{array}{l}11-06-86 \\
10-26-88 \\
12-06-89\end{array}$ & $\begin{array}{l}554 \\
576 \\
694\end{array}$ & $\begin{array}{l}8.0 \\
7.9 \\
8.1\end{array}$ & $\begin{array}{l}23.5 \\
23.5 \\
23.5\end{array}$ & $\begin{array}{l}50 \\
50 \\
78\end{array}$ \\
\hline UJ-62-57-907 & $\begin{array}{l}\text { Gulf States Util. Co., } \\
\text { Sabine, well } 7\end{array}$ & $604-654$ & CHCTL & $\begin{array}{l}11-13-85 \\
11-05-86 \\
11-04-87 \\
10-26-88 \\
12-06-89\end{array}$ & $\begin{array}{r}1,000 \\
1,010 \\
1,000 \\
981 \\
992\end{array}$ & $\begin{array}{l}-- \\
8.1 \\
7.8 \\
7.7 \\
8.0\end{array}$ & $\begin{array}{l}-- \\
25.0 \\
25.0 \\
25.0 \\
25.0\end{array}$ & $\begin{array}{l}220 \\
220 \\
220 \\
220 \\
220\end{array}$ \\
\hline UJ-62-57-908 & $\begin{array}{l}\text { Gulf States Util. Co., } \\
\text { Sabine, well } 8\end{array}$ & $573-623$ & CHCTL & $12-06-89$ & 836 & 8.2 & 24.5 & 170 \\
\hline UJ-62-57-909 & $\begin{array}{l}\text { Gulf States Util. Co., } \\
\text { Sabine, well } 9\end{array}$ & $410-460$ & CHCTL & $\begin{array}{l}11-13-85 \\
11-04-87 \\
10-26-88 \\
12-06-89\end{array}$ & $\begin{array}{l}520 \\
536 \\
524 \\
528\end{array}$ & $\begin{array}{c}-- \\
7.9 \\
7.9 \\
8.1\end{array}$ & $\begin{array}{l}-- \\
24.0 \\
24.0 \\
24.0\end{array}$ & $\begin{array}{l}49 \\
44 \\
46 \\
47\end{array}$ \\
\hline UJ-62-58-304 & $\begin{array}{l}\text { Orange County WCID 2, } \\
\text { well } 1\end{array}$ & $626-706$ & CHCTL & $\begin{array}{l}11-06-85 \\
11-05-86 \\
10-28-87 \\
10-19-88 \\
12-08-89\end{array}$ & $\begin{array}{l}834 \\
835 \\
806 \\
792 \\
851\end{array}$ & $\begin{array}{l}7.4 \\
7.3 \\
7.1 \\
7.4 \\
7.5\end{array}$ & $\begin{array}{l}24.5 \\
24.0 \\
24.5 \\
24.5 \\
24.0\end{array}$ & $\begin{array}{l}170 \\
170 \\
160 \\
140 \\
170\end{array}$ \\
\hline
\end{tabular}


Table 8. Chemical analyses of water from selected wells in Orange County, Texas, 1985-90-Continued

\begin{tabular}{|c|c|c|c|c|c|c|c|c|}
\hline Well number & Owner & $\begin{array}{c}\text { Screened } \\
\text { interval } \\
\text { or depth } \\
\text { (ft) }\end{array}$ & $\begin{array}{c}\text { Water- } \\
\text { bearing } \\
\text { unit }\end{array}$ & $\begin{array}{l}\text { Date of } \\
\text { sample }\end{array}$ & $\begin{array}{c}\text { Specific } \\
\text { conduc- } \\
\text { tance } \\
(\mu \mathrm{S} / \mathrm{cm})\end{array}$ & $\begin{array}{c}\text { pH } \\
\text { (standard } \\
\text { units) }\end{array}$ & $\begin{array}{c}\text { Temper- } \\
\text { ature } \\
\left({ }^{\circ} \mathbf{C}\right)\end{array}$ & $\begin{array}{c}\text { Chloride, } \\
\text { dissolved } \\
(\mathrm{mg} / \mathrm{L})\end{array}$ \\
\hline UJ-62-58-305 & City of Orange, well 8 & $520-610$ & CHCTL & $\begin{array}{l}11-14-85 \\
10-31-86 \\
10-27-87 \\
10-25-88 \\
11-30-89\end{array}$ & $\begin{array}{l}800 \\
805 \\
796 \\
833 \\
847\end{array}$ & $\begin{array}{l}6.9 \\
7.1 \\
6.6 \\
7.2 \\
7.1 \\
\end{array}$ & $\begin{array}{l}24.5 \\
24.0 \\
24.0 \\
24.0 \\
23.5\end{array}$ & $\begin{array}{l}160 \\
160 \\
160 \\
170 \\
180\end{array}$ \\
\hline UJ-62-58-325 & $\begin{array}{l}\text { Orange County WCID 2, } \\
\text { well } 2\end{array}$ & $620-670$ & CHCTL & $\begin{array}{l}11-06-85 \\
11-05-86 \\
10-28-87 \\
10-19-88 \\
12-08-89\end{array}$ & $\begin{array}{l}749 \\
723 \\
723 \\
825 \\
753\end{array}$ & $\begin{array}{l}7.4 \\
7.4 \\
7.1 \\
7.2 \\
7.6\end{array}$ & $\begin{array}{l}24.5 \\
24.0 \\
24.5 \\
24.5 \\
22.5\end{array}$ & $\begin{array}{l}140 \\
150 \\
140 \\
160 \\
140\end{array}$ \\
\hline UJ-62-58-326 & City of Pinehurst, well 2 & $530-600$ & CHCTL & $\begin{array}{l}11-07-85 \\
11-06-86 \\
10-24-88 \\
12-08-89\end{array}$ & $\begin{array}{l}434 \\
465 \\
420 \\
474\end{array}$ & $\begin{array}{l}7.1 \\
7.1 \\
7.3 \\
7.3\end{array}$ & $\begin{array}{l}23.5 \\
24.0 \\
24.0 \\
23.0\end{array}$ & $\begin{array}{l}59 \\
64 \\
55 \\
66\end{array}$ \\
\hline UJ-62-58-402 & Orangefield ISD & $515-535$ & CHCTL & $\begin{array}{l}11-05-85 \\
10-29-86 \\
10-27-87 \\
10-19-88 \\
12-07-89\end{array}$ & $\begin{array}{l}387 \\
402 \\
380 \\
354 \\
556\end{array}$ & $\begin{array}{l}-- \\
-- \\
-- \\
-- \\
7.7\end{array}$ & $\begin{array}{l}-- \\
-- \\
-- \\
-- \\
20.5\end{array}$ & $\begin{array}{l}45 \\
46 \\
46 \\
33 \\
48\end{array}$ \\
\hline UJ-62-58-409 & Johnny Sheppard & $564-651$ & CHCTL & $\begin{array}{l}11-05-85 \\
11-04-86 \\
10-27-87 \\
10-25-88 \\
12-08-89\end{array}$ & $\begin{array}{l}967 \\
974 \\
960 \\
941 \\
365\end{array}$ & $\begin{array}{l}-- \\
-- \\
-- \\
-- \\
8.1\end{array}$ & $\begin{array}{l}-- \\
-- \\
-- \\
-- \\
23.0\end{array}$ & $\begin{array}{r}210 \\
210 \\
210 \\
210 \\
26\end{array}$ \\
\hline UJ-62-58-423 & $\begin{array}{l}\text { Community Water } \\
\text { System }\end{array}$ & $208-215$ & CHCTU & $\begin{array}{l}11-05-85 \\
11-06-86 \\
11-03-87 \\
10-26-88 \\
04-18-90\end{array}$ & $\begin{array}{l}730 \\
801 \\
776 \\
780 \\
802\end{array}$ & $\begin{array}{l}-- \\
-- \\
-- \\
-- \\
7.8\end{array}$ & $\begin{array}{l}-- \\
-- \\
-- \\
-- \\
22.0\end{array}$ & $\begin{array}{l}72 \\
73 \\
70 \\
71 \\
70\end{array}$ \\
\hline UJ-62-58-513 & Bayou Pines Trailer Park & $205-215$ & CHCTU & $\begin{array}{l}11-06-85 \\
10-29-86 \\
10-30-87 \\
10-26-88\end{array}$ & $\begin{array}{l}863 \\
864 \\
857 \\
840\end{array}$ & $\begin{array}{l}-- \\
-- \\
-- \\
--\end{array}$ & $\begin{array}{l}-- \\
-- \\
-- \\
--\end{array}$ & $\begin{array}{l}65 \\
66 \\
71 \\
65\end{array}$ \\
\hline UJ-62-58-514 & Doan's Nursery & 400 & CHCTL & $\begin{array}{l}11-04-87 \\
10-27-88 \\
04-19-90\end{array}$ & $\begin{array}{l}706 \\
704 \\
756\end{array}$ & $\begin{array}{l}-- \\
-- \\
--\end{array}$ & $\begin{array}{l}-- \\
-- \\
--\end{array}$ & $\begin{array}{l}43 \\
42 \\
45\end{array}$ \\
\hline UJ-62-58-515 & Doan's Nursery & 275 & CHCTU & $\begin{array}{l}11-04-87 \\
10-27-88 \\
04-19-90\end{array}$ & $\begin{array}{l}710 \\
697 \\
738\end{array}$ & $\begin{array}{l}-- \\
-- \\
--\end{array}$ & $\begin{array}{l}-- \\
-- \\
--\end{array}$ & $\begin{array}{l}41 \\
44 \\
44\end{array}$ \\
\hline UJ-62-58-605 & $\begin{array}{l}\text { Chevron Chemical Co., } \\
\text { well } 4\end{array}$ & $604-717$ & CHCTL & $\begin{array}{l}11-14-85 \\
11-06-86 \\
11-03-87 \\
10-26-88 \\
12-11-89\end{array}$ & $\begin{array}{l}4,140 \\
4,070 \\
3,870 \\
4,020 \\
1,620\end{array}$ & $\begin{array}{c}7.4 \\
-- \\
7.3 \\
7.4 \\
7.6\end{array}$ & $\begin{array}{l}22.5 \\
-- \\
24.5 \\
24.0 \\
23.5\end{array}$ & $\begin{array}{r}1,200 \\
1,200 \\
1,100 \\
1,200 \\
420\end{array}$ \\
\hline UJ-62-58-606 & $\begin{array}{l}\text { James River Corp., } \\
\text { well } 3\end{array}$ & $630-710$ & CHCTL & $\begin{array}{l}11-07-85 \\
11-03-87 \\
10-25-88 \\
12-11-89\end{array}$ & $\begin{array}{l}1,290 \\
1,350 \\
1,450 \\
1,420\end{array}$ & $\begin{array}{l}7.6 \\
7.5 \\
7.5 \\
7.7\end{array}$ & $\begin{array}{l}25.0 \\
24.5 \\
25.0 \\
24.0\end{array}$ & $\begin{array}{l}330 \\
340 \\
340 \\
350\end{array}$ \\
\hline
\end{tabular}


Table 8. Chemical analyses of water from selected wells in Orange County, Texas, 1985-90-Continued

\begin{tabular}{|c|c|c|c|c|c|c|c|c|}
\hline Well number & Owner & $\begin{array}{c}\text { Screened } \\
\text { interval } \\
\text { or depth } \\
\text { (ft) }\end{array}$ & $\begin{array}{c}\text { Water- } \\
\text { bearing } \\
\text { unit }\end{array}$ & $\begin{array}{l}\text { Date of } \\
\text { sample }\end{array}$ & $\begin{array}{c}\text { Specific } \\
\text { conduc- } \\
\text { tance } \\
(\mu \mathrm{S} / \mathrm{cm})\end{array}$ & $\begin{array}{c}\mathrm{pH} \\
\text { (standard } \\
\text { units) }\end{array}$ & $\begin{array}{c}\text { Temper- } \\
\text { ature } \\
\left({ }^{\circ} \mathbf{C}\right)\end{array}$ & $\begin{array}{c}\text { Chloride, } \\
\text { dissolved } \\
(\mathrm{mg} / \mathrm{L})\end{array}$ \\
\hline UJ-62-58-608 & Allied-Signal Inc. & $620-735$ & CHCTL & $\begin{array}{l}11-06-85 \\
10-30-86 \\
10-29-87 \\
10-18-88 \\
12-12-89\end{array}$ & $\begin{array}{l}1,800 \\
1,760 \\
1,730 \\
1,900 \\
2,760\end{array}$ & $\begin{array}{l}7.5 \\
7.4 \\
7.6 \\
7.4 \\
8.0\end{array}$ & $\begin{array}{l}25.0 \\
24.0 \\
24.0 \\
26.0 \\
22.0\end{array}$ & $\begin{array}{l}480 \\
450 \\
460 \\
540 \\
400\end{array}$ \\
\hline UJ-62-58-609 & $\begin{array}{l}\text { E.I. DuPont Co., } \\
\text { well 103-3 }\end{array}$ & $634-723$ & CHCTL & $\begin{array}{l}11-14-85 \\
11-04-86 \\
11-03-87 \\
10-25-88 \\
12-13-89\end{array}$ & $\begin{array}{r}1,050 \\
1,040 \\
975 \\
203 \\
806\end{array}$ & $\begin{array}{l}7.4 \\
7.7 \\
7.3 \\
7.6 \\
7.8\end{array}$ & $\begin{array}{l}23.5 \\
25.0 \\
24.5 \\
24.0 \\
23.5\end{array}$ & $\begin{array}{r}230 \\
230 \\
220 \\
30 \\
150\end{array}$ \\
\hline UJ-62-58-614 & $\begin{array}{l}\text { E.I. DuPont Co., } \\
\text { well 103-1 }\end{array}$ & 726 & CHCTL & $\begin{array}{l}11-14-85 \\
11-04-86 \\
11-03-87 \\
10-25-88 \\
12-13-89\end{array}$ & $\begin{array}{r}1,270 \\
632 \\
1,230 \\
639 \\
1,230\end{array}$ & $\begin{array}{l}7.3 \\
6.9 \\
7.1 \\
7.6 \\
7.7\end{array}$ & $\begin{array}{l}23.0 \\
25.0 \\
24.5 \\
23.5 \\
19.0\end{array}$ & $\begin{array}{l}300 \\
140 \\
280 \\
110 \\
290\end{array}$ \\
\hline UJ-62-58-615 & $\begin{array}{l}\text { Firestone Petrochemical } \\
\text { Center, well P-817 }\end{array}$ & $611-700$ & CHCTL & $\begin{array}{l}10-20-88 \\
12-12-89\end{array}$ & $\begin{array}{r}924 \\
2,580\end{array}$ & $\begin{array}{l}7.4 \\
7.8\end{array}$ & $\begin{array}{l}25.0 \\
19.5\end{array}$ & $\begin{array}{l}190 \\
740\end{array}$ \\
\hline UJ-62-58-623 & A. Schulman Co. & $440-460$ & CHCTL & $\begin{array}{l}11-06-85 \\
10-30-86 \\
11-03-87 \\
10-26-88 \\
12-13-89\end{array}$ & $\begin{array}{l}430 \\
458 \\
512 \\
395 \\
397\end{array}$ & $\begin{array}{l}-- \\
-- \\
-- \\
-- \\
8.1\end{array}$ & $\begin{array}{l}-- \\
-- \\
-- \\
-- \\
22.5\end{array}$ & $\begin{array}{l}32 \\
34 \\
46 \\
23 \\
25\end{array}$ \\
\hline UJ-62-58-629 & $\begin{array}{l}\text { Firestone Petrochemical } \\
\text { Center, well P-821 }\end{array}$ & $595-680$ & CHCTL & $\begin{array}{l}11-06-85 \\
11-04-86 \\
10-30-87 \\
10-20-88 \\
12-12-89\end{array}$ & $\begin{array}{l}966 \\
932 \\
940 \\
921 \\
933\end{array}$ & $\begin{array}{l}7.6 \\
7.6 \\
7.5 \\
7.5 \\
8.0\end{array}$ & $\begin{array}{l}25.0 \\
24.5 \\
24.5 \\
25.0 \\
23.0\end{array}$ & $\begin{array}{l}210 \\
200 \\
190 \\
190 \\
190\end{array}$ \\
\hline UJ-62-58-631 & $\begin{array}{l}\text { Firestone Petrochemical } \\
\text { Center, well P-825 }\end{array}$ & $585-680$ & CHCTL & $\begin{array}{l}11-06-85 \\
11-04-86 \\
10-30-87\end{array}$ & $\begin{array}{l}3,610 \\
3,690 \\
3,690\end{array}$ & $\begin{array}{l}7.4 \\
7.5 \\
7.1\end{array}$ & $\begin{array}{l}24.5 \\
24.5 \\
24.5\end{array}$ & $\begin{array}{l}1,100 \\
1,060 \\
1,100\end{array}$ \\
\hline UJ-62-58-632 & $\begin{array}{l}\text { Polysar Gulf Coast, Inc., } \\
\text { well } 1\end{array}$ & $640-710$ & CHCTL & $\begin{array}{l}11-07-85 \\
10-30-86 \\
10-29-87 \\
10-19-88 \\
12-12-89\end{array}$ & $\begin{array}{l}1,250 \\
1,240 \\
1,320 \\
1,370 \\
1,330\end{array}$ & $\begin{array}{l}7.6 \\
7.6 \\
7.4 \\
7.3 \\
7.8\end{array}$ & $\begin{array}{l}25.0 \\
24.5 \\
24.5 \\
25.0 \\
21.5\end{array}$ & $\begin{array}{l}300 \\
310 \\
320 \\
320 \\
310\end{array}$ \\
\hline UJ-62-58-633 & $\begin{array}{l}\text { Polysar Gulf Coast, Inc., } \\
\text { well } 2\end{array}$ & $625-725$ & CHCTL & $\begin{array}{l}11-07-85 \\
10-30-86 \\
10-29-87 \\
10-19-88 \\
12-12-89\end{array}$ & $\begin{array}{l}1,970 \\
1,960 \\
1,990 \\
1,220 \\
1,950\end{array}$ & $\begin{array}{l}7.5 \\
7.6 \\
6.9 \\
7.5 \\
8.0\end{array}$ & $\begin{array}{l}24.5 \\
24.5 \\
24.0 \\
24.0 \\
22.0\end{array}$ & $\begin{array}{l}520 \\
530 \\
520 \\
270 \\
500\end{array}$ \\
\hline UJ-62-58-634 & $\begin{array}{l}\text { Polysar Gulf Coast, Inc., } \\
\text { well } 3\end{array}$ & $615-715$ & CHCTL & $12-12-89$ & 1,710 & -- & -- & 420 \\
\hline UJ-62-58-635 & R.C.W., Inc. & $639-689$ & CHCTL & $\begin{array}{l}11-14-85 \\
11-06-86 \\
11-03-87\end{array}$ & $\begin{array}{l}375 \\
370 \\
375\end{array}$ & $\begin{array}{l}7.7 \\
-- \\
--\end{array}$ & $\begin{array}{l}24.5 \\
-- \\
--\end{array}$ & $\begin{array}{l}34 \\
34 \\
31\end{array}$ \\
\hline
\end{tabular}


Table 8. Chemical analyses of water from selected wells in Orange County, Texas, 1985-90-Continued

\begin{tabular}{|c|c|c|c|c|c|c|c|c|}
\hline Well number & Owner & $\begin{array}{c}\text { Screened } \\
\text { interval } \\
\text { or depth } \\
\text { (ft) }\end{array}$ & $\begin{array}{c}\text { Water- } \\
\text { bearing } \\
\text { unit }\end{array}$ & $\begin{array}{l}\text { Date of } \\
\text { sample }\end{array}$ & $\begin{array}{c}\text { Specific } \\
\text { conduc- } \\
\text { tance } \\
(\mu \mathrm{S} / \mathrm{cm})\end{array}$ & $\begin{array}{c}\text { pH } \\
\text { (standard } \\
\text { units) }\end{array}$ & $\begin{array}{c}\text { Temper- } \\
\text { ature } \\
\left({ }^{\circ} \mathrm{C}\right)\end{array}$ & $\begin{array}{c}\text { Chloride, } \\
\text { dissolved } \\
(\mathrm{mg} / \mathrm{L})\end{array}$ \\
\hline UJ-62-58-638 & $\begin{array}{l}\text { Chevron Chemical Co., } \\
\text { well } 6\end{array}$ & $634-735$ & CHCTL & $\begin{array}{l}11-14-85 \\
11-06-86 \\
11-03-87 \\
10-26-88 \\
12-11-89\end{array}$ & $\begin{array}{l}1,650 \\
1,630 \\
1,430 \\
1,480 \\
1,650\end{array}$ & $\begin{array}{l}7.4 \\
7.7 \\
7.4 \\
7.5 \\
7.6\end{array}$ & $\begin{array}{l}24.0 \\
25.0 \\
24.5 \\
24.5 \\
29.5\end{array}$ & $\begin{array}{l}420 \\
400 \\
320 \\
360 \\
430\end{array}$ \\
\hline UJ-62-58-639 & $\begin{array}{l}\text { Polysar Gulf Coast, Inc., } \\
\text { well } 4\end{array}$ & $620-725$ & CHCTL & $\begin{array}{l}11-07-85 \\
10-19-88\end{array}$ & $\begin{array}{l}1,500 \\
1,790\end{array}$ & $\begin{array}{l}7.6 \\
7.5\end{array}$ & $\begin{array}{l}25.0 \\
24.5\end{array}$ & $\begin{array}{l}360 \\
450\end{array}$ \\
\hline UJ-62-58-640 & $\begin{array}{l}\text { Polysar Gulf Coast, Inc., } \\
\text { well } 5\end{array}$ & $612-718$ & CHCTL & $\begin{array}{l}10-30-86 \\
10-24-87 \\
10-19-88 \\
12-12-89\end{array}$ & $\begin{array}{l}1,200 \\
1,250 \\
1,210 \\
1,360\end{array}$ & $\begin{array}{l}7.6 \\
7.6 \\
7.5 \\
8.0\end{array}$ & $\begin{array}{l}24.5 \\
24.0 \\
24.5 \\
24.0\end{array}$ & $\begin{array}{l}280 \\
290 \\
290 \\
310\end{array}$ \\
\hline UJ-62-58-642 & Ernest H. Willey & $420-426$ & CHCTL & $\begin{array}{l}11-06-85 \\
10-30-86 \\
10-28-87 \\
10-26-88 \\
12-07-89\end{array}$ & $\begin{array}{l}409 \\
406 \\
394 \\
399 \\
401\end{array}$ & $\begin{array}{l}-- \\
-- \\
-- \\
-- \\
--\end{array}$ & $\begin{array}{l}-- \\
-- \\
-- \\
-- \\
--\end{array}$ & $\begin{array}{l}21 \\
24 \\
21 \\
21 \\
20\end{array}$ \\
\hline UJ-62-58-701 & Texaco Inc. & 704 & CHCTL & $\begin{array}{l}11-05-86 \\
10-26-88\end{array}$ & $\begin{array}{l}1,030 \\
1,010\end{array}$ & $\begin{array}{l}8.0 \\
7.6\end{array}$ & $\begin{array}{l}24.5 \\
25.0\end{array}$ & $\begin{array}{l}220 \\
220\end{array}$ \\
\hline UJ-62-58-708 & $\begin{array}{l}\text { Gulf States Util. Co., } \\
\text { Sabine, well } 6\end{array}$ & 465 & CHCTL & $\begin{array}{l}11-13-85 \\
11-05-86 \\
11-04-87 \\
12-07-89\end{array}$ & $\begin{array}{l}490 \\
491 \\
519 \\
507\end{array}$ & $\begin{array}{l}-- \\
8.3 \\
7.9 \\
8.1\end{array}$ & $\begin{array}{l}-- \\
24.5 \\
24.0 \\
23.5\end{array}$ & $\begin{array}{l}40 \\
49 \\
41 \\
44\end{array}$ \\
\hline UJ-62-58-709 & $\begin{array}{l}\text { Orange County WCID } 3 \text {, } \\
\text { well } 4\end{array}$ & $617-698$ & CHCTL & $\begin{array}{l}11-13-85 \\
10-28-86 \\
10-29-87 \\
10-20-88 \\
12-07-89\end{array}$ & $\begin{array}{l}1,030 \\
1,050 \\
1,030 \\
1,100 \\
1,120\end{array}$ & $\begin{array}{l}8.0 \\
7.6 \\
7.8 \\
7.6 \\
8.1\end{array}$ & $\begin{array}{l}25.0 \\
25.0 \\
25.0 \\
25.0 \\
25.0\end{array}$ & $\begin{array}{l}220 \\
220 \\
210 \\
240 \\
250\end{array}$ \\
\hline UJ-62-58-809 & $\begin{array}{l}\text { Orange County WCID } 3 \text {, } \\
\text { well } 3\end{array}$ & $570-650$ & CHCTL & $\begin{array}{l}11-13-85 \\
10-28-86 \\
10-29-87 \\
10-20-88\end{array}$ & $\begin{array}{l}1,060 \\
1,070 \\
1,080 \\
1,090\end{array}$ & $\begin{array}{l}8.0 \\
7.9 \\
7.9 \\
8.0\end{array}$ & $\begin{array}{l}25.0 \\
25.0 \\
25.0 \\
25.0\end{array}$ & $\begin{array}{l}220 \\
220 \\
220 \\
220\end{array}$ \\
\hline UJ-62-58-810 & P.J. Silkwood & $160-170$ & CHCTU & $\begin{array}{l}11-13-85 \\
10-28-86 \\
10-29-87 \\
10-18-88 \\
12-07-89\end{array}$ & $\begin{array}{l}1,200 \\
1,190 \\
1,200 \\
1,200 \\
1,140\end{array}$ & $\begin{array}{c}7.5 \\
-- \\
-- \\
-- \\
7.8\end{array}$ & $\begin{array}{l}23.0 \\
-- \\
-- \\
-- \\
21.0\end{array}$ & $\begin{array}{l}210 \\
210 \\
210 \\
210 \\
190\end{array}$ \\
\hline UJ-62-59-101 & City of Orange, well 7 & $555-666$ & CHCTL & $\begin{array}{l}11-14-85 \\
10-31-86 \\
10-27-87 \\
10-25-88 \\
11-30-89\end{array}$ & $\begin{array}{l}790 \\
794 \\
798 \\
809 \\
819\end{array}$ & $\begin{array}{l}7.3 \\
7.4 \\
7.1 \\
7.4 \\
7.5\end{array}$ & $\begin{array}{l}24.5 \\
24.0 \\
24.0 \\
24.0 \\
23.5\end{array}$ & $\begin{array}{l}150 \\
150 \\
150 \\
150 \\
150\end{array}$ \\
\hline UJ-62-59-123 & City of Orange, well 9 & $529-643$ & CHCTL & $\begin{array}{l}10-25-88 \\
11-30-89\end{array}$ & $\begin{array}{l}382 \\
375\end{array}$ & $\begin{array}{l}7.2 \\
7.5\end{array}$ & $\begin{array}{l}24.0 \\
23.0\end{array}$ & $\begin{array}{l}32 \\
36\end{array}$ \\
\hline UJ-62-59-124 & Equitable Bag Co. & $590-640$ & CHCTL & $\begin{array}{l}11-15-85 \\
11-05-86 \\
11-02-87 \\
10-27-88 \\
04-19-90\end{array}$ & $\begin{array}{l}750 \\
744 \\
773 \\
777 \\
802\end{array}$ & $\begin{array}{l}7.1 \\
7.2 \\
6.9 \\
7.4 \\
7.4\end{array}$ & $\begin{array}{l}24.5 \\
24.0 \\
24.0 \\
24.0 \\
24.0\end{array}$ & $\begin{array}{l}150 \\
140 \\
160 \\
150 \\
160\end{array}$ \\
\hline
\end{tabular}

